I19.3:1729-D

\title{
Mineral Resources of the Clover Mountains Wilderness Study Area, Lincoln County, Nevada
}

\section{U.S. GEOLOGICAL SURVEY BULLETIN 1729-D}

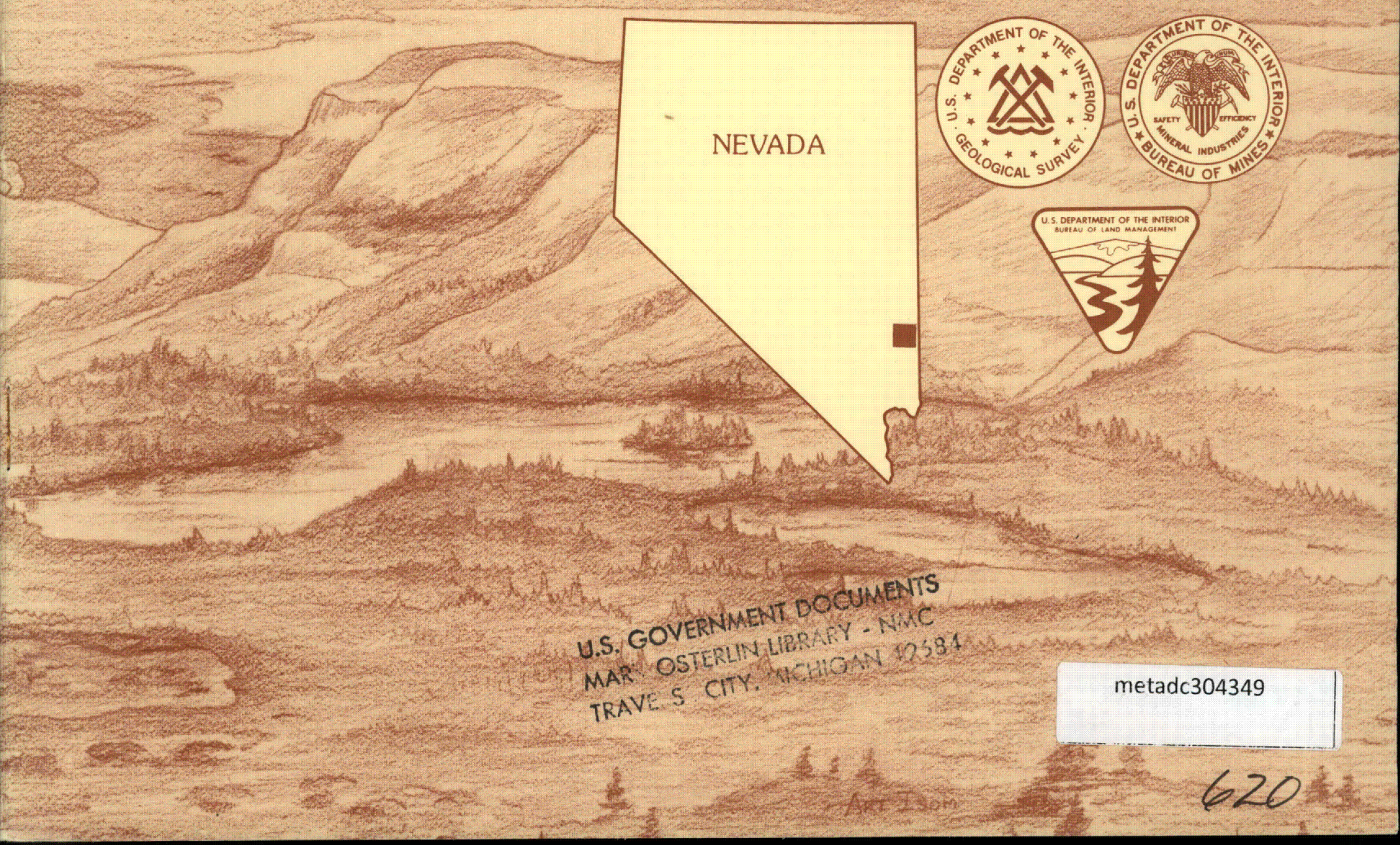



Chapter D

\section{Mineral Resources of the Clover Mountains Wilderness Study Area, Lincoln County, Nevada}

By BARRY MORING, H. RICHARD BLANK, Jr., and JAMES D. HOFFMAN

U.S. Geological Survey

EDWARD L. MCHUGH

U.S. Bureau of Mines

U.S. GEOLOGICAL SURVEY BULLETIN 1729

MINERAL RESOURCES OF WILDERNESS STUDY AREAS:

SOUTHEASTERN NEVADA 
DEPARTMENT OF THE INTERIOR

DONALD PAUL HODEL, Secretary

U.S. GEOLOGICAL SURVEY

Dallas L. Peck, Director

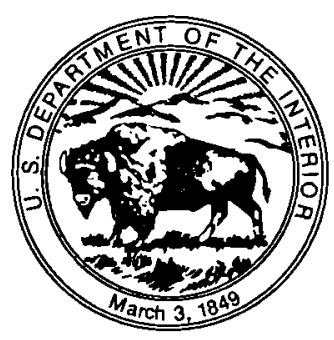

Any use of trade names and trademarks in this publication is for descriptive purposes only and does not constitute endorsement by the U.S. Geological Survey

For sale by the

Books and Open-File Reports Section

U.S. Geological Survey

Federal Center, Box 25425

Denver, CO 80225

Library of Congress Cataloging-in-Publication Data

Mineral resources of the Clover Mountains Wilderness

Study Area, Lincoln County, Nevada.

(U.S. Geological Survey bulletin ; 1729-D)

Bibliography: p.

1. Mines and mineral resources-Nevada-Clover

Mountains Wilderness. 2. Clover Mountains Wilderness

(Nev.) I. Moring, Barry, C. II. Series.

QE75.B9 no. 1729-D $557.3 \mathrm{~s}$

[TN24.N3]

[553'.09793'14]

88-600195 


\section{STUDIES RELATED TO WILDERNESS}

\section{Bureau of Land Management Wilderness Study Area}

The Federal Land Policy and Management Act (Public Law 94-579, October 21, 1976) requires the U.S. Geological Survey and the U.S. Bureau of Mines to conduct mineral surveys on certain areas to determine the mineral values, if any, that may be present. Results must be made available to the public and be submitted to the President and the Congress. This report presents the results of a mineral survey of part of the Clover Mountains Wilderness Study Area (NV-050-139), Lincoln County, Nevada. 



\section{CONTENTS}

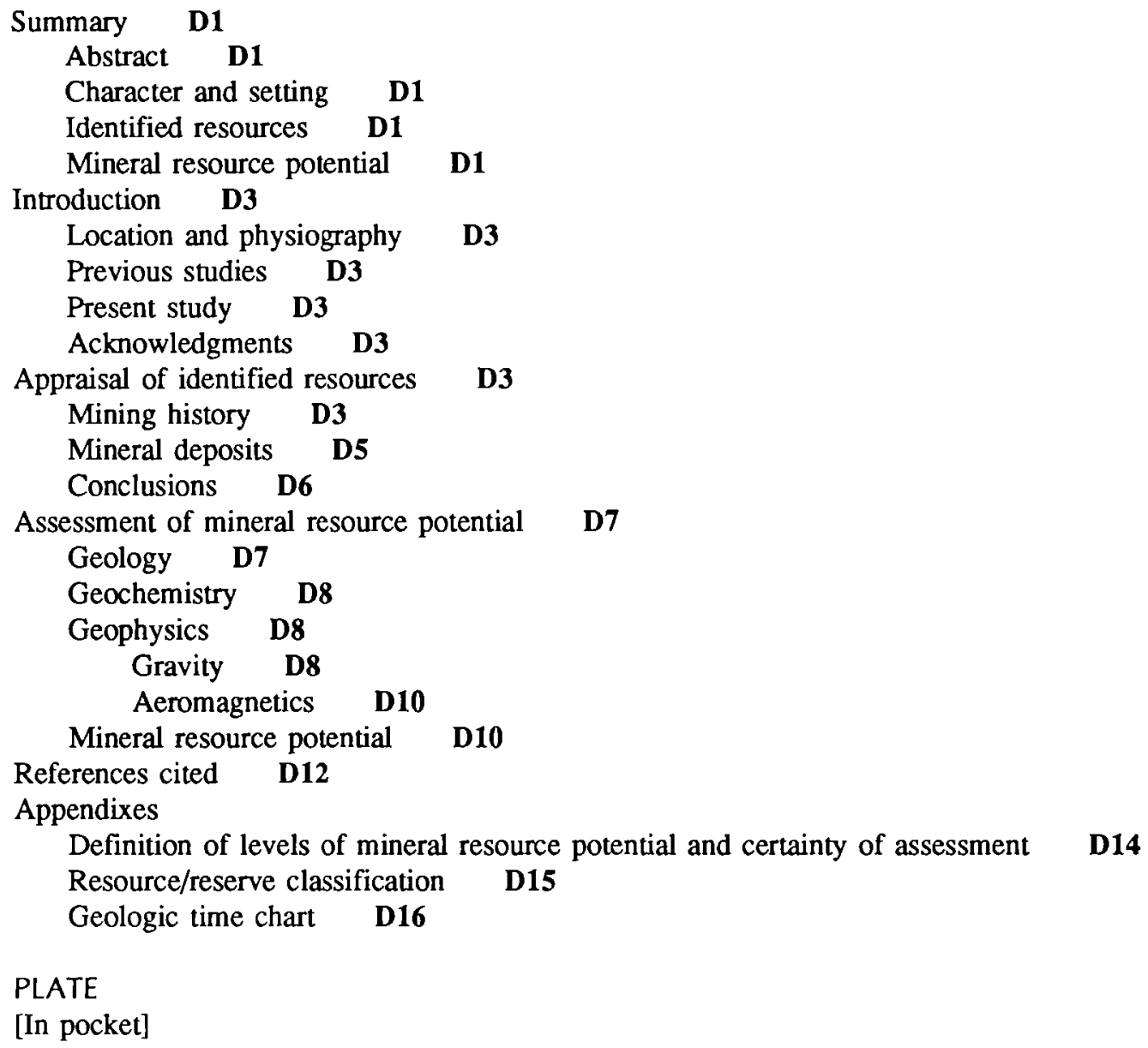

[In pocket]

1. Mineral resource potential map of the Clover Mountains Wilderness Study Area, Lincoln County, Nevada

\section{FIGURES}

1. Index map showing location of the Clover Mountains Wilderness Study Area, Lincoln County, Nevada D2

2. Map showing mineral resource potential and generalized geology of the Clover Mountains Wilderness Study Area, Lincoln County, Nevada D4

3. Map showing Bouguer gravity data for the Clover Mountains Wilderness Study Area, Lincoln County, Nevada D9

4. Map showing aeromagnetic data for the Clover Mountains Wilderness Study Area, Lincoln County, Nevada D11

TABLE

1. Mines and prospects in and adjacent to the Clover Mountains Wilderness Study area, Lincoln County, Nevada 



\title{
Mineral Resources of the Clover Mountains Wilderness Study Area, Lincoln County, Nevada
}

\author{
By Barry Moring, H. Richard Blank, Jr., and James D. Hoffman \\ U.S. Geological Survey
}

\author{
Edward L. McHugh \\ U.S. Bureau of Mines
}

\section{SUMMARY}

\begin{abstract}
At the request of the U.S. Bureau of Land Management, approximately 84,165 acres of the Clover Mountains Wilderness Study Area (NV-050-139) was evaluated for mineral resources (known) and mineral resource potential (undiscovered). In this report, the area studied is referred to as "the wilderness study area" or simply "the study area;" any reference to the Clover Mountains Wilderness Study Area refers only to that part of the wilderness study area for which a mineral survey was requested by the U.S. Bureau of Land Management. The study area is located in southern Nevada, in Lincoln County, about $90 \mathrm{mi}$ northeast of Las Vegas. No identified mineral resources exist inside the study area, although gold, silver, and copper resources are found immediately to the west at the Pennsylvania mine. Two parts of the study area have moderate mineral resource potential for molybdenum. A large portion of the southern part of the study area has low mineral resource potential for gold, silver, oil, gas, and zeolite mineral resources. A small area adjacent to the west boundary of the study area has low potential for gold and silver.
\end{abstract}

\section{Character and Setting}

The Clover Mountains Wilderness Study Area is located in the southeastern part of Nevada about $20 \mathrm{mi}$ south of Caliente and $90 \mathrm{mi}$ northeast of Las Vegas (fig. 1). The study area is characterized by a rugged terrain of moderate to steep slopes dissected by intermittently active drainages.

Manuscript approved for publication May 27, 1988.
The elevation of the study area ranges from about $3,040 \mathrm{ft}$ along Meadow Valley Wash to $7,555 \mathrm{ft}$ at Sawmill Mountain (fig. 2).

The study area straddles the south margin of the Caliente cauldron and is underlain by silicic volcanic or volcaniclastic rocks of Miocene age (see appendixes for Geologic Time Chart) of the cauldron complex. These rocks overlie quartzite, limestone, and shale of Paleozoic and Mesozoic age that are exposed outside the study area.

\section{Identified Resources}

No identified mineral resources exist within the study area, although gold, silver, and copper resources lie $0.5 \mathrm{mi}$ to the west at the Pennsylvania mine where open-pit mining and heap leaching of ore from a quartz-breccia zone in diorite began in 1986. By October 1986, about 2,000 oz of gold and 15,000 oz of silver had been recovered.

\section{Mineral Resource Potential}

Areas having moderate potential for molybdenum and low potential for gold, silver, zeolites, and oil and gas have been delineated in the Clover Mountains Wilderness Study Area (fig. 2). Two areas in the northern part of the study area are characterized by molybdenum, tin, zinc, niobium, manganese, lanthanum, and yttrium geochemical anomalies in stream-sediment samples, and by the presence of highsilica rhyolite (quartz porphyry) dikes. Such features indicate a moderate mineral resource potential for molybdenum in stockwork-molybdenite deposits in these areas. 
In the southern part of the study area, along and south of the margin of the Caliente cauldron complex, the coincidence of areas of hydrothermally altered volcanic rocks and scattered occurrences of anomalous concentrations of gold, silver, and arsenic in rock samples suggests the presence of epithermal precious-metal deposits. Most of this area has low mineral resource potential for gold and silver.
The presence of zeolites in some of the altered rocks suggests that the same area has low mineral potential for zeolite resources. A small area on the west border of the study area immediately east of the Pennsylvania mine also has low mineral resource potential for gold and silver. There is low potential for oil and gas within the southern part of the study area.

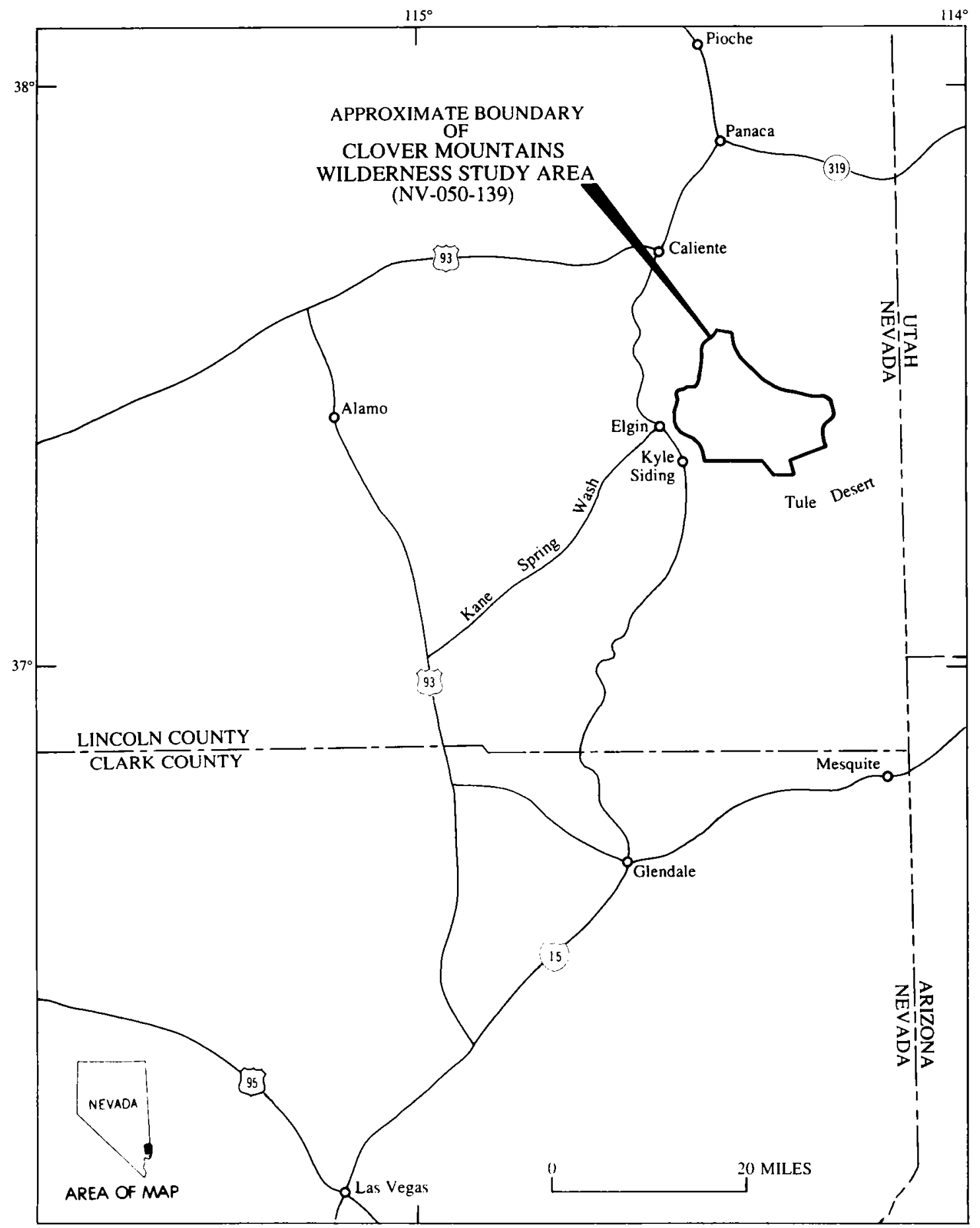

Figure 1. Index map showing location of the Clover Mountains Wilderness Study Area, Lincoln County, Nevada. 


\section{INTRODUCTION}

This mineral survey was requested by the U.S. Bureau of Land Management and is a joint effort by the U.S. Geological Survey and the U.S. Bureau of Mines. An introduction to the wilderness review process, mineral survey methods, and agency responsibilities is provided by Beikman and others (1983). The U.S. Bureau of Mines evaluates identified resources at individual mines and known mineralized areas by collecting data on current and past mining activities and through field examination of mines, prospects, claims, and mineralized areas. Identified resources are classified according to the system that is a modification of that described by McKelvey (1972) and U.S. Bureau of Mines and U.S. Geological Survey. U.S. Geological Survey studies are designed to provide a scientific basis for assessing the potential for undiscovered mineral resources by determining geologic units and structures, possible environments of mineral deposition, presence of geochemical and geophysical anomalies, and applicable ore-deposit models. Goudarzi (1984) discusses mineral assessment methodology and terminology as they apply to these surveys. See appendixes for the definition of levels of resource potential and certainty of assessment and for the resource/reserve classification.

\section{Location and Physiography}

The Clover Mountains Wilderness Study Area consists of 84,165 acres in southeastern Nevada. It is located in southeastem Lincoln County about $90 \mathrm{mi}$ northeast of Las Vegas and $20 \mathrm{mi}$ south of Caliente, Nev. (fig. 1). The study area is bounded on the west by Meadow Valley Wash and Pennsylvania Canyon, on the north and east by roads on Stokes Flat and Sheep Flat and along Sams Camp Wash, and on the south by roads from the Tule Desert. The study area is characterized by moderate to steep slopes dissected by the largely ephemeral streams of the Cottonwood Canyon drainage basin. Elevations within the study area range from about $3,040 \mathrm{ft}$ at the southwest corner of the study area in Meadow Valley Wash to 7,555 $\mathrm{ft}$ on Sawmill Mountain in the northeast corner. At elevations above $5,000 \mathrm{ft}$, much of the study area is covered by piñon-juniper forest with groves of oak, cottonwood, and ponderosa pine along some drainages. A sparse desert brushland of mainly sage and creosote lies below $5,000 \mathrm{ft}$.

\section{Previous Studies}

Tschanz and Pampeyan (1970) described geology and mineral deposits in and near the study area in their report on Lincoln County. The Tertiary geology of the county was further described by Ekren and others (1977). Reports prepared for the U.S. Bureau of Land Management describe geology, energy, and minerals (Great Basin GEM Joint
Venture, 1983) and reconnaissance geochemistry of the study area and vicinity.

\section{Present Study}

Work by the U.S. Bureau of Mines entailed library research, fieldwork, and report-preparation phases that spanned 1984 through 1986. Pertinent literature and Lincoln County and U.S. Bureau of Land Management mining and mineral-lease records were reviewed. All known mines, prospects, and claims in and near the study area were examined and, where warranted, were mapped and sampled.

A total of 132 rock samples were collected and analyzed at the U.S. Bureau of Mines laboratory in Reno, Nev., for gold and silver by fire-assay or combined fireassay and inductively coupled plasma (ICP) methods. Presence and abundance of identified or suspected elements of possible economic significance were determined by ICP, atomic-absorption, fluorometric, radiometric, X-ray fluorescence, or semiquantitative-emission spectrographic methods. A monitoring scintillometer was used to test for radioactivity in the field. Detailed analytic methods and results were given by McHugh (1987) and are available from the U.S. Bureau of Mines, Western Field Operations Center, E. 360 Third Avenue, Spokane, WA 99202.

The U.S. Geological Survey carried out field investigations intermittently between 1983 and March of 1986. This work included geochemical sampling and analysis (Hoffman and Day, 1984), geologic mapping (R.L. Elliott, and K.R. Leonard, written communs., 1985, 1986), and collection and interpretation of gravity, aeromagnetic, and aerial radiometric data.

\section{Acknowledgments}

Geologists Richard Rains and Terry Neumann, U.S. Bureau of Mines, and Raymond L. Elliott, Jay A. Sampson, and Ken R. Leonard, U.S. Geological Survey, aided greatly during field investigations. Information and assistance provided by U.S. Bureau of Land Management personnel of the District Office in Caliente, Nev., and by Thomas Johnston, owner of the Pennsylvania mine, are very much appreciated.

\section{APPRAISAL OF IDENTIFIED RESOURCES}

By Edward L. McHugh

U.S. Bureau of Mines

\section{Mining History}

Eleven mines and prospects are situated in or just outside the Clover Mountains Wildemess Study Area, but 
no mineral production has come from within the study area. Mine development in the Clover Mountains began in the Pennsylvania district, just west of the study area, in 1871 (Carlson, 1974); low-grade gold ore had been produced from the Pennsylvania mine by 1881 (Angel, 1958). The Viola (Cherokee) mining district is located outside the south boundary of the study area and was active by the 1880 's.
Total production from the Pennsylvania district until 1986 was approximately $\$ 70,000$ in gold, silver, lead, and copper. About 190 claims have been located in the district since 1889; 139 claims were current in July 1984. The current claims encompass the old Pennsylvania mine (fig. 2 , No. 1) and nearby workings, and some extend into the study area. A proposal to mine by open pit and extract gold by a heap-leach process on site at the Pennsylvania mine

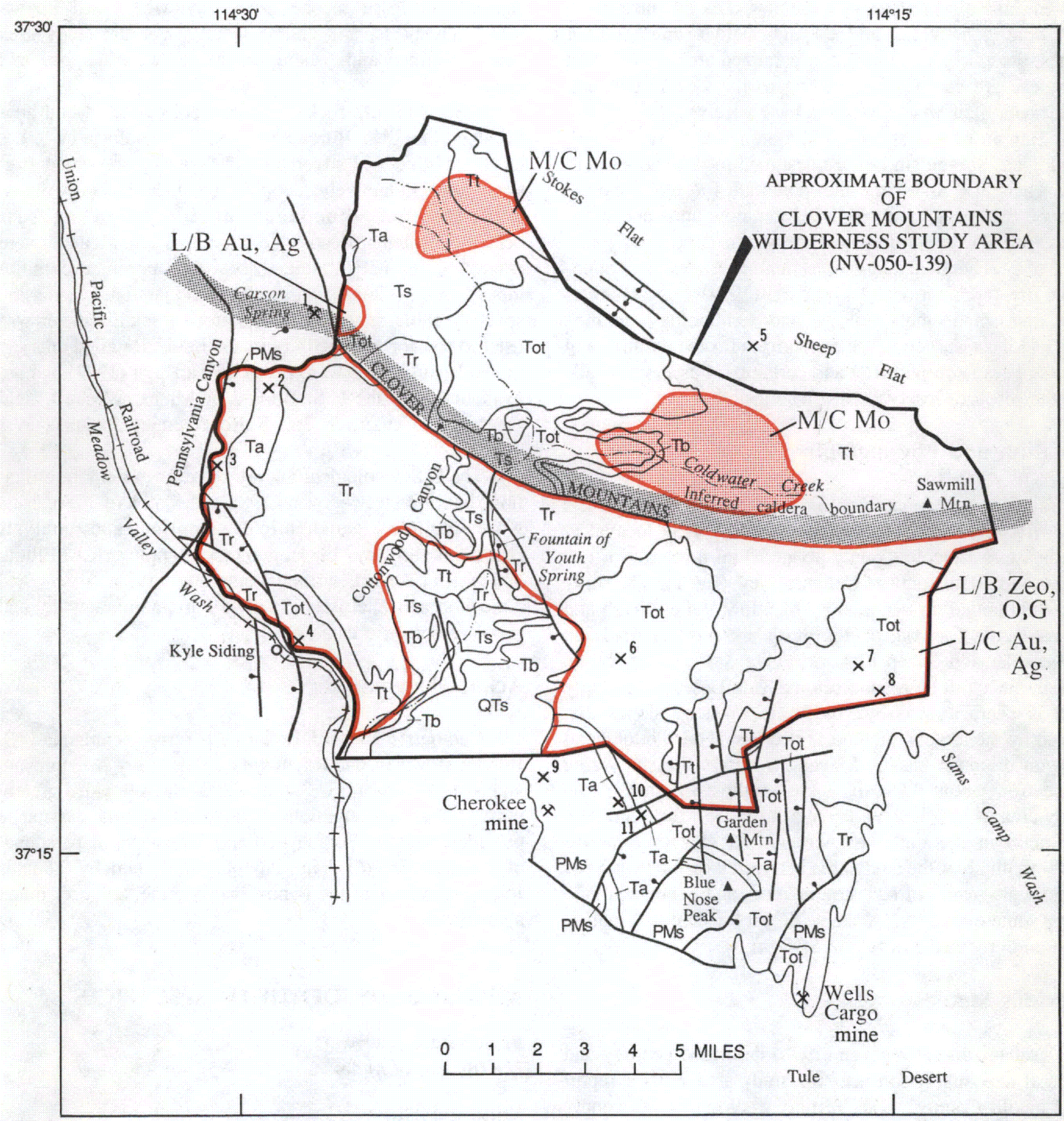

Figure 2. Map showing mineral resource potential and generalized geology of the Clover Mountains Wilderness Study Area, Lincoln County, Nevada. 
was approved by U.S. Bureau of Land Management in 1984. Fisher-Watt Mining Company, under a lease agreement with the owners, began mining in April 1986. About 90,000 tons of ore having an average ore grade of about $0.02 \mathrm{oz} /$ ton was mined mainly from the Jumbo pit, which is south of the old Pennsylvania workings. By October 1986 , about $2,000 \mathrm{oz}$ gold and $15,000 \mathrm{oz}$ silver had been recovered.

More than 400 claims were located south of the study area in the Viola district between 1891 and 1947. Produc-

\section{EXPLANATION}

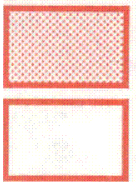

Area with moderate mineral resource potential (M)

Area with low mineral resource potential (L)

Level of certainty of assessment

B Data only suggest level of potential

C Data give good indication of level of potential

\section{Commodities}

$\begin{array}{ll}\text { Mo } & \text { Molybdenum } \\ \mathrm{Ag} & \text { Silver } \\ \mathrm{Au} & \text { Gold } \\ \text { Zeo } & \text { Zeolite } \\ \mathrm{O}, \mathrm{G} & \text { Oil and gas }\end{array}$

Mine and prospects

$\begin{array}{ll}\text { 1. } & \text { Pennsylvania mine } \\ 2 . & \text { Iron Blossom prospect } \\ 3 . & \text { Bobcat prospect } \\ 4 . & \text { Kyle Siding prospect } \\ 5 . & \text { Grandview prospect } \\ 6 . & \text { Yon prospect } \\ 7 . & \text { Gold } 23-31 \text { prospect } \\ 8 . & \text { Gold 1-22 prospect } \\ 9 . & \text { Wall Street prospect } \\ 10 . & \text { Gold Chance prospect } \\ 11 . & \text { Cherokee } 1-12 \text { prospect }\end{array}$

Geologic map units

\begin{tabular}{|c|c|}
\hline QTs & Surficial deposits (Quatemary and Tertiary) \\
\hline $\mathrm{Tt}$ & Tuffaceous rocks (Tertiary) \\
\hline Ts & Sedimentary rocks (Tertiary) \\
\hline $\mathrm{Tb}$ & Basalt (Tertiary) \\
\hline $\mathrm{Tr}$ & Rhyolite (Tertiary) \\
\hline Tot & Older tuffaceous rocks (Tertiary) \\
\hline Тa & Andesite (Tertiary) \\
\hline PMs & Sedimentary rocks (Paleozoic and Mesozoic) \\
\hline & Contact \\
\hline 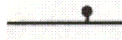 & Fault-Bar and ball on downthrown side \\
\hline & Inferred caldera margin \\
\hline$x^{6}$ & Prospect or mine-Numbers refer to table 1 \\
\hline
\end{tabular}

Figure 2. Continued. tion of silver and copper ore from the patented Cherokee mine probably totaled less than 500 tons (Tschanz and Pampeyan, 1970). The Wells Cargo fluorspar mine, about $4 \mathrm{mi}$ south of the study area, was developed in 1957 . In $1958,11,500$ tons of fluorspar (commercial fluorite) valued at $\$ 363,000$ was mined from the deposit. These mines were idle in 1985.

Mining activity along Meadow Valley Wash includes the Boyd clay mine, $5.7 \mathrm{mi}$ west of the study area, which was worked intermittently between 1920 and 1930, and the Boyd alunite mine, which produced three carloads of alunite for use as fertilizer (Hewett and others, 1936). About 43 claims were located in or near the study area between the mouth of Pennsylvania Canyon and Kyle Siding from 1904 to 1958; none were active in 1984.

More recent exploration activity includes drilling of a molybdenum target near the south boundary of the study area about $1 \mathrm{mi}$ northwest of Blue Nose Peak in the mid1970's (William Walker, Canyon Resources Corp., oral commun., 1985); no development ensued. In 1980, Houston International Minerals Corporation located 147 claims (Yon prospect, fig. 2, No. 6) inside the southern part of the study area. The claims were reportedly for molybdenum and have been subsequently dropped (Great Basin GEM Joint Venture, 1983). Also in 1980, the Bethex Corporation located two blocks of claims (Gold 1-22 and Gold 23-31, fig. 2, Nos. 7 and 8) mostly inside the southeastern part of the study area. These claims have also been abandoned.

Silver and gold targets were explored in the vicinity of Blue Nose Peak (fig. 2) by Canyon Resources Corporation, Golden, Colo. A block of 151 current claims covers many of the old workings and extends to within $1 \mathrm{mi}$ of the study area. Mineralization occurred in association with silicified zones in limestone near depositional contacts with overlying volcanic rocks. Evaluation of the property continued in 1985 (William Walker, Canyon Resources Corp., written commun., 1985).

Earth Sciences, Inc. of Golden, Colo., applied for a permit to prospect for alunite $2 \mathrm{mi}$ east of the study area (Great Basin GEM Joint Venture, 1983). The possible alunite resources, an extension of deposits to the east in Utah, were to be part of a pilot project to evaluate processes and assess the economics of alumina recovery from alunite (Parkinson, 1974).

\section{Mineral Deposits}

Mineralized rocks are abundant along the west and south sides of the study area. However, no mineral resources were identified within the study area.

Along the west side of the study area, in the Pennsylvania mine area, Cambrian limestone and quartzite were intruded by a diorite stock. A silicified breccia zone in the 
diorite at the Pennsylvania mine (fig. 2, No. 1) that dips gently toward and may extend beneath the study area contains gold, silver, and copper. Thermal metamorphism and metasomatic alteration of the Cambrian sedimentary rocks along the contact with the diorite produced calc-silicate rocks containing epidote and calcium garnet; oxidized parts of the altered zones contain malachite and hematite pseudomorphs after chalcopyrite. Shear zones in carbonate rocks along the east side of Pennsylvania Canyon contain silver, lead, and zinc.

Along the south boundary of the study area in the Viola (Cherokee) district, faulted blocks of Paleozoic and Mesozoic carbonate rocks, shale, and quartzite have been locally mineralized. Sedimentary rocks inside the study area are mostly covered by Tertiary volcanic rocks. Masses of jasperoid are present along the contacts between sedimentary and volcanic rocks. Altered limestone near depositional contacts with extrusive rocks in this district contain silver, copper, lead, zinc, and mercury; some limestone also contains appreciable quantities of cadmium, antimony, and molybdenum (Tschanz and Pampeyan, 1970). Gypsum occurs in Mesozoic red beds, and manganese and fluorspar deposits occur in limestone 1 to $4 \mathrm{mi}$ south of the study area.

Evidence of mining or prospecting activity was found at 11 sites in or just outside the study area (fig. 2). Table 1 briefly describes the sites examined. An identified gold and silver resource block at the Pennsylvania mine is situated just outside the study area. The mine owner (Thomas Johnston, oral commun., 1985) estimated a resource at the deposit of 700,000 tons containing $0.039 \mathrm{oz} /$ ton gold. A reserve block within the deposit of 100,000 tons containing $0.11 \mathrm{oz} /$ ton gold and 1.0 to $1.5 \mathrm{oz} / \mathrm{ton}$ silver was identified by the current operators, and 90,000 tons was mined in 1986. Continuing resource evaluation by the operators is expected to identify additional ore (Bud Hillemeyer, oral commun., 1986).

At the Bobcat prospect (fig. 2, No. 3), a porous, hematitic breccia zone and silicified chert-pebble conglomerate are mineralized, but no resources were identified. South of the study area boundary at the Gold Chance and Cherokee 1-12 prospects (fig. 2, Nos. 10 and 11), the contact between Paleozoic limestone and Tertiary andesite is silicified and mineralized, but again no resources were identified.

Paleozoic sedimentary rocks and Tertiary volcanic rocks like those found in the study area are known to host precious-metal mineralization in other parts of the region . Areas of moderate to intense hydrothermal alteration inside the study area were observed by Ekren and others (1977). The alteration generally circumscribes the inferred boundary of the Caliente caldera, and affects both Paleozoic and Tertiary rocks. Twenty-seven rock-chip samples from outcrops both in and outside the delineated altered areas were analyzed for gold, silver, arsenic, antimony, and mercury. Detection limits for these analysis are 7 parts per billion (ppb) for gold, 0.3 parts per million (ppm) for silver, $2 \mathrm{ppm}$ for arsenic, $2 \mathrm{ppm}$ for antimony, and $2 \mathrm{ppm}$ for mercury. Two samples contain 43 and $135 \mathrm{ppb}$ gold. Twenty-one of these samples contain 0.35 to $3.939 \mathrm{ppm}$ silver. Seven samples contain 4 to $14.3 \mathrm{ppm}$ arsenic. Antimony was not detected in any samples. No resources were identified.

An area northeast of the Pennsylvania mine in the northwest corner of the study area appears to have anomalous concentrations of thorium on the basis of U.S. Department of Energy aerial radiometric-survey maps (Geo-Life, 1980 , table 8). Fourteen of the 27 outcrop samples were from this zone; they contain 5.3 to $7.8 \mathrm{ppm}$ uranium and 30 to $55 \mathrm{ppm}$ thorium. Scintillometer traverses revealed no anomalous levels of radioactivity in the study area.

One sample of altered tuff from near the Fountain of Youth Spring (fig. 2) was analyzed by X-ray diffraction for zeolites; it contains about 65 percent clinoptilolite. No concentrations of alunite were observed in the study area.

Occurrences of stone, sand, and gravel within the study area could be used for local construction. The most readily accessible sites are in drainages along Meadow Valley Wash and in Cottonwood and Pennsylvania Canyons.

\section{Conclusions}

Samples from surface exposures in the Pennsylvania mine area disclose no identified resources but reveal consistently anomalous amounts of gold and silver in the mineralized quartz-breccia zone. Resource estimates by the owner are based on extensive geologic mapping, drilling, and sampling. General cost estimates based on the owner's extraction plan suggest that the deposit is a demonstrated marginal reserve, although parts of this deposit were being mined in 1986. No evidence indicates that the mineralized breccia zone extends into the study area along strike to the south of the mine. The down-dip extension of the zone, assuming continuity and constant northeasterly dip, would be about $1,800 \mathrm{ft}$ deep at the study area boundary. The faulted blocks of Paleozoic sedimentary rocks to the south are altered and locally contain gold and base metals, but no substantial mineralized structure was found. The study area boundary excludes nearly all of the sedimentary rocks near the Pennsylvania mine. The depth to pre-Cenozoic sedimentary rocks in areas underlain by late Tertiary volcanic rocks is not known, however.

Small amounts of gold, silver, and other elements were detected at other prospects or altered zones inside the study area. Mineralized zones at the Bobcat prospect (fig. 2, No. 3) are too discontinuous and gold and silver content too low to constitute resources.

Outside the south boundary of the study area, silver content is consistently anomalous at the Wall Street, Gold Chance, and Cherokee 1-12 prospects (fig. 2, Nos. 9, 10, 
and 11). However, the silver concentrations are well below those that are indicative of silver resources. Anomalous amounts of molybdenum were also measured in samples from these prospects. Silver, barium, lead, molybdenum, tin, and zinc are also present adjacent to these prospects. Substantial amounts of fluorspar and manganese are present to the south (Wells Cargo mine, fig. 2).

Slightly anomalous amounts of thorium were found in the study area but are too low to suggest the presence of resources. Uranium content in the samples is within the range expected for felsic igneous rocks (Rose and others, 1979).

Stone, sand, and gravel inside the study area along Meadow Valley Wash could be used in road and railroad construction and maintenance. Development of such construction materials at other sites in the study area is unlikely because of their inaccessibility and remoteness.

\section{ASSESSMENT OF MINERAL RESOURCE POTENTIAL}

By Barry Moring, H. Richard Blank, Jr., and

James D. Hoffman

U.S. Geological Survey

\section{Geology}

The Clover Mountains Wilderness Study Area is underlain mostly by volcanic rocks associated with the Caliente cauldron complex of Ekren and others (1977). These rocks are dominantly rhyolitic ash-flow tuff and postcaldera sedimentary rocks and also include andesite and basalt. Faulted and folded Paleozoic and Mesozoic sedimentary rocks crop out outside the caldera margin and presumably underlie the downdropped caldera block (pl. 1).

Paleozoic and Mesozoic sedimentary rocks form small but prominent exposures in Pennsylvania Canyon along the west border of the study area and north of the Tule Desert near the south border. These rocks crop out in the study area only in the Pennsylvania Canyon area; other exposures lie more than $0.5 \mathrm{mi}$ outside the wilderness study area boundary.

The exposed bedrock in the Pennsylvania Canyon area is of Cambrian age and consists of the Prospect Mountain Quartzite, the Pioche Shale, and limestone of the Highland Peak Formation (Tschanz and Pampeyan, 1970). Both the quartzite and limestone are massively bedded and form resistant outcrops. The intervening shale is generally less than $200 \mathrm{ft}$ thick and forms debris-covered slopes.

Alteration of the Cambrian strata in Pennsylvania Canyon is of two types: (1) at the Bobcat prospect (fig. 2, No. 3), hydrothermal alteration has produced discontinuous breccia zones filled with quartz, opal, galena, and pyrite (McHugh, 1987), and (2) south of the Pennsylvania mine (fig. 2, No. 1), contact metasomatism of limestone adjacent to Tertiary diorite has produced a copper-stained, gamet, epidote, and idocrase skarn.

South of the study area, outcrops of pre-Cenozoic rocks consist of Mississippian to Triassic limestone (including the Toroweap Formation and Kaibab Limestone) and continental red beds of shale, siltstone, and sandstone (Moenkopi Formation in part) (Tschanz and Pampeyan, 1970). Locally, the limestone has been altered and silicified. For example, alteration at the Cherokee mine consists of hematite-stained, brecciated shear zones that contain anomalous amounts of lead, zinc, and silver in silicified limestone (McHugh, 1987). Elsewhere in the district, jasperoid bodies have formed at the contact between the limestone and the overlying Tertiary andesite. Hydrothermal fluorspar has replaced limestone at the Wells Cargo mine (fig. 2) (Tschanz and Pampeyan, 1970).

Tertiary rocks underlie more than 90 percent of the study area. The oldest of these is an Eocene(?) lacustrine limestone and conglomerate unit less than $100 \mathrm{ft}$ thick. This unit unconformably overlies Paleozoic rocks in Pennsylvania Canyon (Tschanz and Pampeyan, 1970). The remainder of the Tertiary rocks are volcanic or volcaniclastic sedimentary rocks of Miocene age.

The earliest evidence of volcanic activity adjacent to the study area is basalt and porphyritic andesite flows exposed near the west and south borders of the study area. These flows are less than $100 \mathrm{ft}$ thick and overlie the lacustrine rocks in Pennsylvania Canyon and the Paleozoic and Mesozoic rocks in the Viola mining district.

Following the eruption of these flows, the area became a major volcanic center with formation of the Caliente cauldron complex (Ekren and others, 1977). This complex is composed of several overlapping calderas that range in age from about 23 to $12 \mathrm{Ma}$; it measures 40 by $18 \mathrm{mi}$ and is elongate along an east-west axis. The study area straddles the south margin of this complex.

The Caliente cauldron complex appears to have been the source of several regional ash-flow tuffs including the Harmony Hills Tuff (23-20 Ma), Racer Canyon Tuff (20-18 Ma), Hiko Tuff (19-17 Ma), and Ox Valley Tuff (15-12 Ma). These tuffs are dacitic to rhyolitic and have a composite thickness in excess of $3,000 \mathrm{ft}$ in the study area. Intercalated with these tuffs are rhyolite, andesite, and basalt flows. A diorite that may be penecontemporaneous with the earliest of the ash-flow tuffs crops out near the Pennsylvania mine.

Quartz-porphyry dikes cross-cut the youngest of the ash flows in the Coldwater Creek area (fig. 2). These rocks have quartz phenocrysts as large as 0.25 in. across and small, highly altered biotite crystals in a gray aphanitic matrix. The dikes form indistinct outcrops but are as thick as $15 \mathrm{ft}$ and have a general east-west trend that approximately parallels the inferred south caldera margin. These dikes appear to be a late-stage high-silica rhyolite intrusion related to the waning of caldera activity. 
The west lobe of the caldera has resurged, but elsewhere the margin is covered by welded tuff and postcaldera volcaniclastic sedimentary rocks and rhyolite flows. The volcaniclastic rocks are probably caldera fill (Ekren and others, 1977).

Evidence for at least four stages of tectonic activity are present in the study area. The earliest stage produced folds and cleavage within the Paleozoic and Mesozoic rocks. The second episode was responsible for the unroofing and tilting of Paleozoic and Mesozoic strata. This was followed by faulting associated with caldera activity and collapse between about 23 and $12 \mathrm{Ma}$. Finally, the area was faulted along post-caldera, northwest-trending, basin-and-range style faults. Faults and fractures associated with both the caldera formation and basin-and-range faulting have been important in localizing later hydrothermal fluids that altered and mineralized parts of the study area.

\section{Geochemistry}

A total of 40 rock, 136 stream-sediment, and 133 nonmagnetic heavy-mineral-concentrate samples were collected from the study area by the U.S. Geological Survey (Hoffman and Day, 1984). Samples were analyzed for 31 elements using a six-step semiquantitative-emission spectrographic method (Grimes and Marranzino, 1968).

Inspection of the data on heavy-mineral concentrates indicates areas that have anomalous concentrations of barium and thorium along the west edge of the study area (Hoffman and Day, 1984). The barium anomalies appear to be associated with an area of moderately to intensely hydrothermally altered rhyolitic and tuffaceous rocks mapped by Ekren and others (1977). These anomalies probably represent minor hydrothermal veining. Thorium is probably derived from accessory heavy minerals such as monazite that commonly occur in the rhyolitic rocks. Neither the barium or thorium anomalies indicate significant potential for mineral deposits.

Inspection of the stream-sediment data indicates that samples from the Coldwater Creek area contain anomalous amounts of molybdenum (5-30 ppm), tin (10-20 ppm), zinc $(200-300 \mathrm{ppm})$, manganese $(1,500-5,000 \mathrm{ppm})$, lanthanum, (100-500 ppm), yttrium (100-200 ppm), niobium (greater than $100 \mathrm{ppm}$ ), and zirconium (greater than 1,000 ppm). These elements are consistent with those common to molybdenum-porphyry systems (Cox, 1986; Theodore, 1986). A second area, west of Stokes Flat, yielded a few samples that contain anomalous concentrations of the same element suite. This clustering of anomalies is, at least in part, spatially associated with quartz-porphyry dikes that lie sub-parallel to the caldera margin. The coincidence of the anomalies and dikes suggests a deeply buried stockworkmolybdenite system. Resampling of rocks and stream sediments in the Coldwater Creek area in 1985 failed to disclose any additional anomalous samples (R.L. Elliott, written commun., 1986).

\section{Geophysics}

The Clover Mountains Wilderness Study Area lies on the south flank of the Caliente cauldron complex (Noble, 1968; Noble and McKee, 1972; Ekren and others, 1977) and is only a few miles northeast of the Kane Springs Wash eruptive center (Noble, 1968; Novak, 1984). Intrusive bodies and volcano-tectonic structures of importance in assessment of mineral resource potential may be concealed beneath the extensive cover of volcanic and surficial deposits in the area. Delineation of such features is facilitated by use of regional gravity and aeromagnetic data.

Gravity data have been obtained from files of the National Defense Mapping Agency (DMA) through the Center for Geophysical and Solar-Terrestrial data (Boulder, CO 80303), supplemented by data from 80 new gravity stations established in the Clover Mountains and vicinity during October-November 1986. The DMA data are included in a published Bouguer anomaly map of the Caliente $1^{\circ}$ by $2^{\circ}$ sheet (Healey and others, 1981), which has been interpreted by Snyder (1983). Aeromagnetic data were obtained from a regional survey flown on north-south lines at 1-mi spacing and 9,000-ft barometric altitude (U.S. Geological Survey, 1973). A published aeromagnetic map of the Caliente $1^{\circ}$ by $2^{\circ}$ sheet incorporating this and other surveys is also available (Saltus and Snyder, 1986).

In addition, widely spaced aeroradiometric traverses over the area have been carried out in conjunction with the National Uranium Resource Evaluation (NURE) program. From a study of these data, J.S. Duval of the U.S. Geological Survey reports (written commun., 1985) “*** overall moderate radioactivity, with values of $1.7-2.5$ percent potassium, 2.5-3.5 ppm equivalent uranium, and 14-30 ppm equivalent thorium. There are no potassium or uranium anomalies within the boundaries of the area or in the immediate vicinity. A moderate thorium anomaly occurs in the northern tip of the area." The thorium anomaly may be associated with a granitic intrusion inferred from the aeromagnetic data, as is discussed in a later section. In general, the background levels of potassium, uranium, and thorium are commensurate with those to be expected in volcanic terrane that includes abundant rocks of rhyolitic composition.

\section{Gravity}

A complete Bouguer gravity anomaly map of the Clover Mountains Wilderness Study Area and vicinity is shown in figure 3. Standard U.S. Geological Survey procedures were followed in reducing values of observed gravity to Bouguer anomalies; terrain corrections were made from digital topographic data out to a distance of 100 
$\mathrm{mi}(167 \mathrm{~km})$ from each station (see, for example, Cordell and others, 1982). No corrections were made manually. A reduction density of $2.67 \mathrm{~g} / \mathrm{cm}^{3}$ was used throughout.

Anomaly relief over the area of the map is approximately $80 \mathrm{mGals}$. The principal features of the anomaly field are (1) a strong down-to-the-north gradient across the south third of the map area, (2) a system of depressions in the north third of the map area, and (3) a depression in the southern Delamar Mountains. Although the wilderness study area is nearly surrounded by these features, the anomaly field within it is loosely constrained and consists mainly of a weak down-to-the-northeast gradient.
The strong north-south gradient is a segment of a firstorder regional gradient belt that extends westward through southern Nevada into California and eastward into southwestern Utah. As has been pointed out by Eaton and others (1978), this gradient roughly coincides with the southern limit of voluminous silicic volcanism in the Great Basin and also with an abrupt decrease of average regional elevationtoward the south. Eaton and others (1978) calculate the depth to the causative density discontinuity to be a maximum of $7.5 \pm .9 \mathrm{mi}$. They further show that the discontinuity must involve mainly crustal rocks and speculate that it represents the south margin of voluminous middle- to

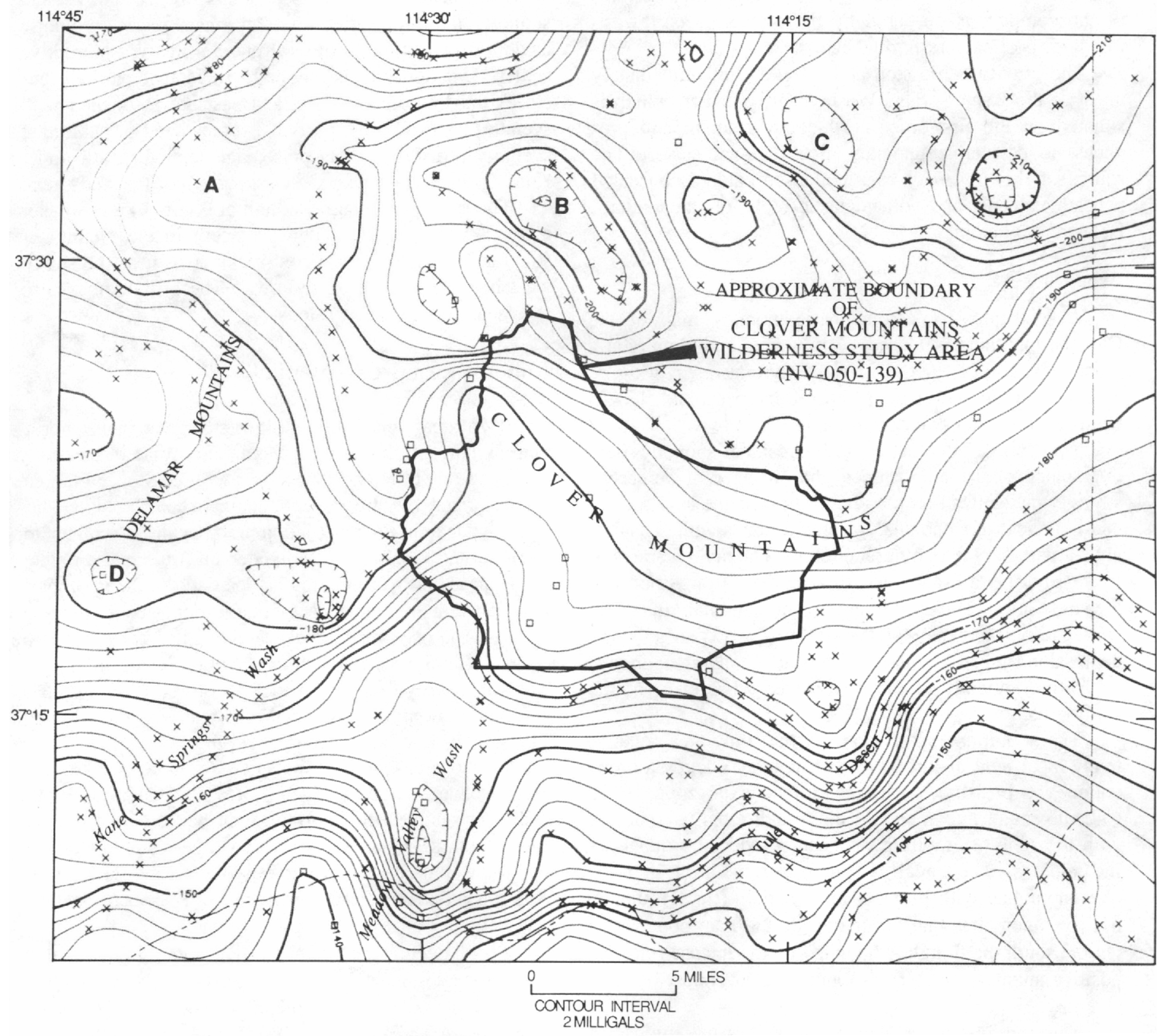

Figure 3. Map showing Bouguer gravity data for the Clover Mountains Wilderness Study Area, Lincoln County, Nevada. Squares and $x$ 's show location of the gravity stations; hachures indicate depressions; letters A-D discussed in text. 
upper-crustal silicic intrusions. In the vicinity of the Clover Mountains the north-south gradient can be partly accounted for by a sharp change in depth to the Proterozoic crystalline basement. North of the gradient, relatively light silicic intrusive and volcanic rocks are both present in large volumes above the basement, resulting in a decrease of the mean upper-crustal density.

Gravity-anomaly depressions north of the study area are associated with the Caliente cauldron complex. The minima centers near A, B, and C (fig. 3) are aligned roughly east-west and delineate the axial zone of the complex. The weak northeasterly anomaly gradient within the study area is possibly the signature of a partial ring fracture. In general, the gravity expression of ring fractures of the complex is obscured by the effects of northwesttrending, post-caldera normal faults.

The gravity depression at D (fig. 3) lies immediately north of the Kane Springs Wash eruptive center, which is situated on the first-order north-south gradient and produces no detectable anomaly at a regional scale. The source of this low may be a collapsed caldera concealed beneath volcanic and volcaniclastic rocks of the southern Delamar Mountains.

\section{Aeromagnetics}

A total-intensity aeromagnetic-anomaly map of the Clover Mountains Wilderness Study Area and vicinity at a drape elevation of $1,000 \mathrm{ft}$ above terrain is shown in figure 4. An International Geomagnetic Reference Field (IGRF) has been removed from the data.

The "noisy" character of the residual-anomaly field over much of the map reflects the presence of numerous strongly magnetized rock bodies at or near the land surface and is typical of Cenozoic volcanic terranes with considerable structural and topographic relief. The main features of interest are (1) a broad east-west anomaly trough north of the study area, (2) a curvilinear positive anomaly that traverses the northern part of the study area, (3) an anomaly depression, ringed by highs, west of the study area, and (4) a positive anomaly at the extreme east boundary of the study area.

The area immediately north of the study area contains many local field disturbances that together occupy a broad anomaly depression, or trough, in the axial zone of the Caliente cauldron complex. This trough roughly coincides with the zone of gravity depressions produced by coalescing calderas. The trough is bounded on the north by positive anomalies with maxima at A and B (fig. 4) and by positive anomalies that occur outside the map boundaries. On the south the trough is bounded by the intense ring-like positive anomaly at $\mathrm{C}$ (fig. 4 ) and by a sub-linear positive anomaly.

The curvilinear positive feature across the study area extends for about $28 \mathrm{mi}$ in an approximately east-west direction. It has two intense maxima: at $D$ (fig. 4 ) in the northern part of the study area, and immediately west of D on the northwest boundary of the study area. Silicic intrusive rocks crop out in the vicinity of the western maximum; elsewhere, the rocks associated with the anomaly are mainly lavas and tuffs of the Caliente cauldron complex. Analysis of anomaly gradients at D (fig. 4) yield a depthto-source estimate of $3,200 \mathrm{ft}$ below the surface. The high at $D$ (fig. 4) may indicate the presence of a concealed intrusion. The sub-linear anomaly as a whole probably represents the combined effects of local intrusions and strongly magnetized lavas on the south flank of the cauldron complex.

The anomaly low west of the study area (E, fig. 4) coincides with a deep gravity-anomaly low (see above) and supports the proposition that an older, buried collapse caldera is present north of the Kane Springs Wash eruptive center. Maxima on the anomaly ridge that partially encloses the low on the south and east are associated with syenite plugs. On this basis it is considered possible that syenitic intrusive rock is present at depth beneath upper Kane Springs Wash near the west margin of the study area.

The strong aeromagnetic high at F (fig. 4) and weaker highs $5-10 \mathrm{mi}$ to the southwest occur in the vicinity of structurally elevated Paleozoic rocks at or near the southwest boundary of the study area. These highs may also represent concealed intrusions.

\section{Mineral Resource Potential}

Two areas, one along Coldwater Creek in the northcentral part of the Clover Mountains Wilderness Study Area and one to the northwest just west of Stokes Flat, are characterized by stream-sediment geochemical anomalies of molybdenum, tin, zinc, niobium, manganese, lanthanum, yttrium, and zirconium. Molybdenum, tin, zinc, niobium, manganese, and yttrium are characteristic of the geochemical signature of granite-molybdenite deposits (Ludington, 1986). The occurrence of these anomalies corresponds to areas underlain by high-silica rhyolite (quartz-porphyry) dikes that are younger than the ash-flow tuff sheets. The association of molybdenum deposits with rhyolite porphyry dikes is well established (Cox, 1986; Theodore, 1986). These two areas have a moderate resource potential for molybdenum, certainty level C (fig. 2). Analysis of the sediment samples for fluorine might better define the certainty of assessment of these two areas, but exploratory drilling would be necessary to raise the certainty level to $\mathrm{D}$. See appendixes for definition of mineral resource potential and certainty of assessment.

Post-caldera, fracture-controlled hydrothermal-alteration processes have been important in the formation of deposits of gold, silver, mercury, and some industrial minerals. An area of hydrothermal alteration in the southem part of the study area is associated with the south margin of the Caliente cauldron complex and may represent 
the results of the hydrothermal-alteration processes described above. Coincident with this altered area are scattered low levels of gold, silver, and arsenic in rock-chip samples (McHugh, 1987). The metal content of these samples is not high enough to represent a deposit, but detailed mapping and sampling could possibly delineate areas with higher concentrations. Thus a large portion of the southern part of the study area has been assigned a low potential for gold and silver in precious-metal epithermal deposits, certainty level C. Detailed geologic mapping and geochemical sampling within this area would be required to further define any possible exploration targets and change the level of certainty and perhaps the level of assessment.
Significant amounts of zeolite minerals have been identified in altered rocks in at least one area (McHugh, 1987). The areal distribution of zeolite minerals is unknown, but the geology is permissive for a low mineral resource potential for zeolite minerals with a certainty level of $B$ in the same altered area described above. This designation could be changed by widespread mineralogical studies of rock samples from within the altered area.

The west edge of the study area immediately east of the Pennsylvania mine has low potential, certainty level B, for gold and silver. A constant projection of the ore body at Pennsylvania mine would intercept the study area 1,800 $\mathrm{ft}$ below the west boundary (McHugh, 1987). Although the

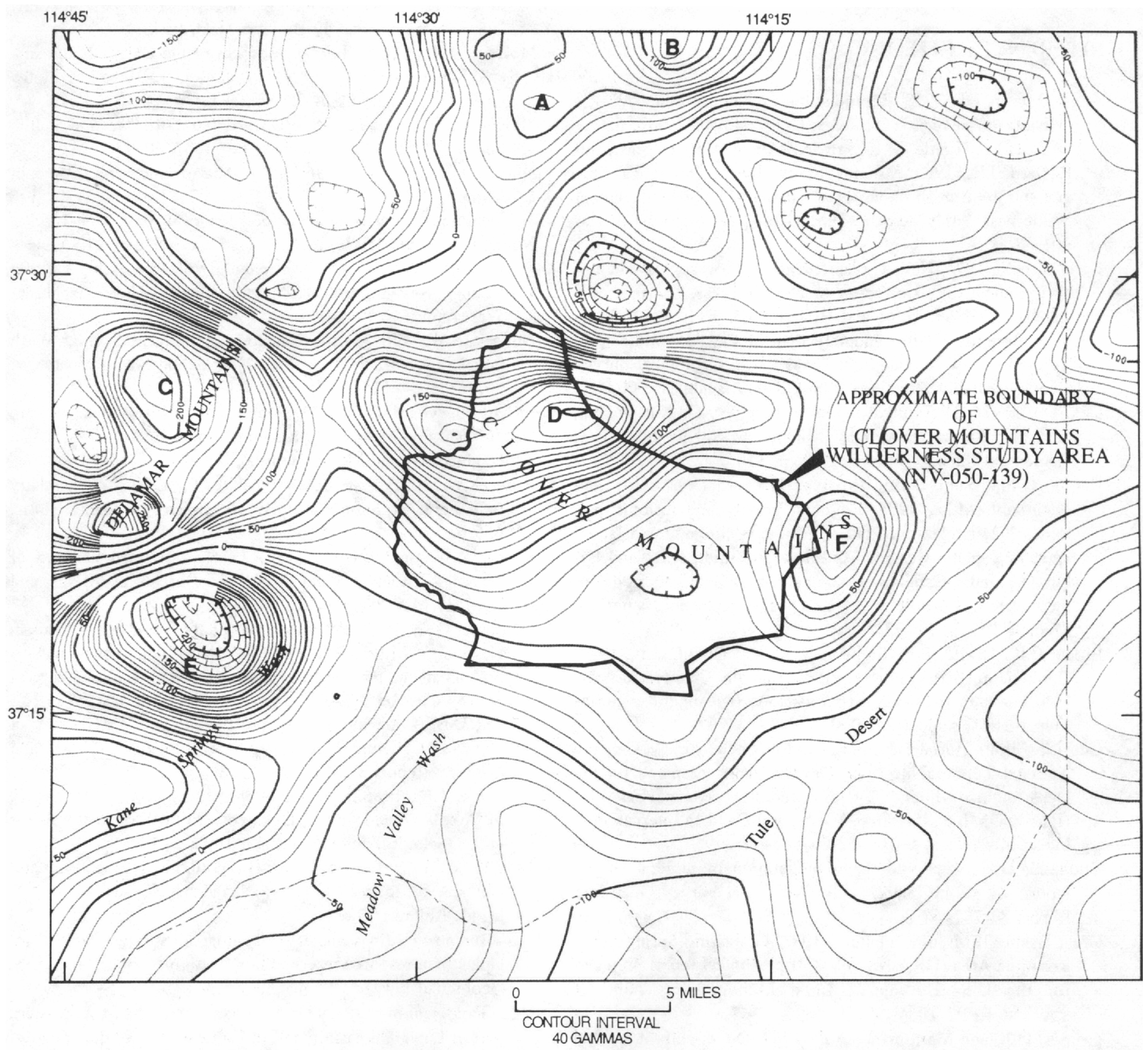

Figure 4. Map showing aeromagnetic data for the Clover Mountains Wilderness Study Area, Lincoln County, Nevada. Hachures indicate depressions; letters $A-F$ discussed in text. 
consistency of this projection is highly speculative considering the distance $(0.5 \mathrm{mi})$, faulting, and the chance of multiple caldera margins, the possibility of a down-dip extension of the zone of mineralization at the mine cannot be totally discarded.

There is low oil and gas resource potential outside (south of) the caldera margin in the study area, certainty level B. Sandberg (1983) included the study area in his "cluster 7" where Cretaceous and Tertiary source beds may have reached thermal maturity and therefore the cluster has a low petroleum potential. Thermal maturation of the Paleozoic rocks had not been tested at the time of Sandburg's study.

\section{REFERENCES CITED}

Angel, Myron, ed., 1958, Reproduction of Thompson and West's "History of Nevada:" Berkeley, Calif., Howell-North, 680 p.

Beikman, H.M., Hinkle, M.E., Frieders, Twila, Marcus, S.M., and Edward, J.R., 1983, Mineral surveys by the Geological Survey and the Bureau of Mines of Bureau of Land Management Wilderness Study Areas: U.S. Geological Survey Circular 901, $28 \mathrm{p}$.

Carlson, H.S., 1974, Nevada place names, a geographical dictionary: Reno, Nev., University of Nevada Press, 282 p.

Cordell, L.E., Geller, G.R., and Hildenbrand, T.G., 1982, Complete Bouguer gravity anomaly map of the Rio Grande rift, Colorado, New Mexico, and Texas: U.S. Geological Survey Geophysical Investigations Map GP-949, scale 1:1,000,000.

Cox, D.P., 1986, Descriptive model of porphyry Cu-Mo, in Cox, D.P., and Singer, D.A., eds., Mineral deposit models: U.S. Geological Survey Bulletin 1693, p. 115.

Eaton, G.P., Wahl, R.R., Prostka, H.J., Mabey, D.R., and Kleinkopf, M.D., 1978, Regional gravity and tectonic patterns: Their relation to late Cenozoic epeirogeny and lateral spreading in the western Cordillera, in Smith, R.B., and Eaton, G.P., eds., Cenozoic tectonics and regional geophysics of the western Cordillera: Geological Society of American Memoir 152, p. 51-92.

Ekren, E.B., Orkild, P.P., Sargent, K.A., and Dixon, G.L., 1977, Geologic map of Tertiary rocks, Lincoln County, Nevada: U.S. Geological Survey Miscellaneous Investigations Series Map I-1041, scale 1:250,000.

Geo-Life, 1980, Aerial radiometric and magnetic survey, Caliente National Topographic Map, Nevada/Utah: prepared for the Department of Energy by joint venture between High Life Helicopters, Inc., Puyallup, Wash., and Geodata International, Inc., Dallas, Tex., GJBX-52(80), 65 p.

Goudarzi, G.H., 1984, Guide to preparation of mineral survey reports on public lands: U.S. Geological Survey Open-File Report 84-787, 51 p.

Great Basin GEM Joint Venture, 1983, Grapevine Spring GEM Resource Area (GRA No. NV-23): technical report prepared for the U.S. Bureau of Land Management (contract YA-554-RFP2-1054), 36 p.

Grimes, D.J., and Marranzino, A.P., 1968, Direct-current arc and alternating-current spark emission spectrographic field methods for the semiquantitative analysis of geologic materials:
U.S. Geological Survey Bulletin 591, 6 p.

Healey, D.L., Snyder, D.B., Wahl, R.R., and Currey, F.E., 1981, Bouguer gravity map of Nevada-Caliente Sheet: Nevada Bureau of Mines and Geology Map 70, scale 1:250,000.

Hewett, D.F., Callaghan, Eugene, Moore, B.N., Nolan, T.B., Rubey, W.W., and Schaller, W.T., 1936, Mineral resources of the region around Boulder Dam: U.S. Geological Survey Bulletin 871, $197 \mathrm{p}$.

Hoffman, J.D., and Day, G.W., 1984, Reconnaissance geochemical assessment of the Clover Mountains Bureau of Land Management Wilderness Study Area (NV-050-139), Lincoln County, Nevada: U.S. Geological Survey Open-File Report OF 84-654, 35 p.

Ludington, S.D., 1986, Descriptive model of Climax Mo deposits, in Cox, D.P. and Singer, D.A. eds., Mineral deposit models: U.S. Geological Survey Bulletin 1693, p. 73.

McHugh, E.L., 1987, Mineral resources of the Clover Mountains study area, Lincoln County, Nevada: U.S. Bureau of Mines Open-File Report MLA 28-87, 29 p.

McKelvey, V.E., 1972, Mineral resource estimates and public policy: American Scientist, v. 60, p. 32-40.

Noble, D.C., 1968, Kane Springs Wash volcanic center, Lincoln County, Nevada, in Eckel, E.H., ed., Nevada Test Site: Geological Society of America Memoir 110, p. 109-116.

Noble, D.C., and McKee, E.H., 1972, Description and K-Ar ages of volcanic units of the Caliente volcanic field, Lincoln County, Nevada, and Washington County, Utah: Isochron/ West, no. 5, p. 17-24.

Novack, S.W., 1984, Eruptive history of the Kane Springs Wash volcanic center, Nevada: Joumal of Geophysical Research, v. 89 , p. $8603-8615$.

Parkinson, Gerald, 1974, Golden pilot plant points way to 500,000 -tpy alumina-from-alunite mine and plant in Utah: Engineering and Mining Journal, August, p. 75-78.

Rose, A.W., Hawkes, H.E., and Webb, J.S., 1979, Geochemistry in mineral exploration, 2nd ed.: London, Academic Press, $655 \mathrm{p}$.

Saltus, R.W., and Snyder, D.B., 1986, Aeromagnetic map of Nevada-Caliente Sheet: Nevada Bureau of Mines and Geology Map 89, scale 1:250,000.

Sandberg, C.A., 1983, Petroleum potential of wilderness lands in Nevada, in Miller, B.M., ed., Petroleum potential of wilderness lands in the western United States: U.S. Geological Survey Circular 902-H, $11 \mathrm{p}$.

Snyder, D.B., 1983, Interpretation of the Bouguer gravity map of Nevada-Caliente Sheet: Nevada Bureau of Mines and Geology Report 37, 8 p.

Theodore, T.G., 1986, Descriptive model of porphyry Mo, low-F, in Cox, D.P., and Singer, D.A., eds., Mineral deposit models: U.S. Geological Survey Bulletin 1693, p. 120.

Tschanz, C.M., and Pampeyan, E.H., 1970, Geology and mineral deposits of Lincoln County, Nevada: Nevada Bureau of Mines Bulletin 73, 187 p.

U.S. Bureau of Mines and U.S. Geological Survey, 1980, Principles of a resource/reserve classification for minerals: U.S. Geological Survey Circular 831, 5 p.

U.S. Geological Survey, 1973, Aeromagnetic map of southeastem part of Lund and eastern half of Caliente $1^{\circ} \times 2^{\circ}$ quadrangles, Nevada: U.S. Geological Survey Open-File Report 73-298, scale $1: 250,000$. 
APPENDIXES; TABLE 1 


\section{DEFINITION OF LEVELS OF MINERAL RESOURCE POTENTIAL AND CERTAINTY OF ASSESSMENT}

\section{LEVELS OF RESOURCE POTENTIAL}

$\mathrm{H}$ HIGH mineral resource potential is assigned to areas where geologic, geochemical, and geophysical characteristics indicate a geologic environment favorable for resource occurrence, where interpretations of data indicate a high degree of likelihood for resource accumulation, where data support mineral-deposit models indicating presence of resources, and where evidence indicates that mineral concentration has taken place. Assignment of high resource potential to an area requires some positive knowledge that mineral-forming processes have been active in at least part of the area.

M MODERATE mineral resource potential is assigned to areas where geologic, geochemical, and geophysical characteristics indicate a geologic environment favorable for resource occurrence, where interpretations of data indicate reasonable likelihood for resource accumulation, and (or) where an application of mineral-deposit models indicates favorable ground for the specified type(s) of deposits.

$\mathrm{L} \quad$ LOW mineral resource potential is assigned to areas where geologic, geochemical, and geophysical characteristics define a geologic environment in which the existence of resources is permissive. This broad category embraces areas with dispersed but insignificantly mineralized rock, as well as areas with little or no indication of having been mineralized.

N NO mineral resource potential is a category reserved for a specific type of resource in a well-defined area.

$\mathrm{U}$ UNKNOWN mineral resource potential is assigned to areas where information is inadequate to assign a low, moderate, or high level of resource potential.

\section{LEVELS OF CERTAINTY}

A Available information is not adequate for determination of the level of mineral resource potential.

B Available information only suggests the level of mineral resource potential.

C Available information gives a good indication of the level of mineral resource potential.

D Available information clearly defines the level of mineral resource potential.

\begin{tabular}{|c|c|c|c|}
\hline A & B & C & $\mathrm{D}$ \\
\hline \multirow{4}{*}{ UNKNOWN POTENTIAL } & $\begin{array}{c}\text { H/B } \\
\text { HIGH POTENTIAL }\end{array}$ & $\begin{array}{c}\mathrm{H} / \mathrm{C} \\
\text { HIGH POTENTIAL }\end{array}$ & $\begin{array}{c}\text { H/D } \\
\text { HIGH POTENTIAL }\end{array}$ \\
\hline & $\begin{array}{c}\text { M/B } \\
\text { MODERATE POTENTIAL }\end{array}$ & $\begin{array}{c}\mathrm{M} / \mathrm{C} \\
\text { MODERATE POTENTIAL }\end{array}$ & $\begin{array}{c}\text { M/D } \\
\text { MODERATE POTENTIAL }\end{array}$ \\
\hline & $\begin{array}{c}\text { L/B } \\
\text { LOW POTENTIAL }\end{array}$ & $\begin{array}{c}\text { L/C } \\
\text { LOW POTENTIAL }\end{array}$ & $\begin{array}{c}\text { L/D } \\
\text { LOW POTENTIAL }\end{array}$ \\
\hline & & & $\begin{array}{c}\text { N/D } \\
\text { NO POTENTIAL }\end{array}$ \\
\hline
\end{tabular}

Abstracted with minor modifications from:

Taylor, R.B., and Steven, T.A., 1983, Definition of mineral resource potential: Economic Geology, v. 78, no. 6, p. $1268-1270$.

Taylor, R.B., Stoneman, R.J., and Marsh, S.P., 1984, An assessment of the mineral resource potential of the San Isabel National Forest, south-central Colorado: U.S. Geological Survey Bulletin 1638, p. 40-42.

Goudarzi, G.H., compiler, 1984, Guide to preparation of mineral survey reports on public lands: U.S. Geological Survey Open-File Report 84-0787, p. 7, 8. 


\section{RESOURCE/RESERVE CLASSIFICATION}

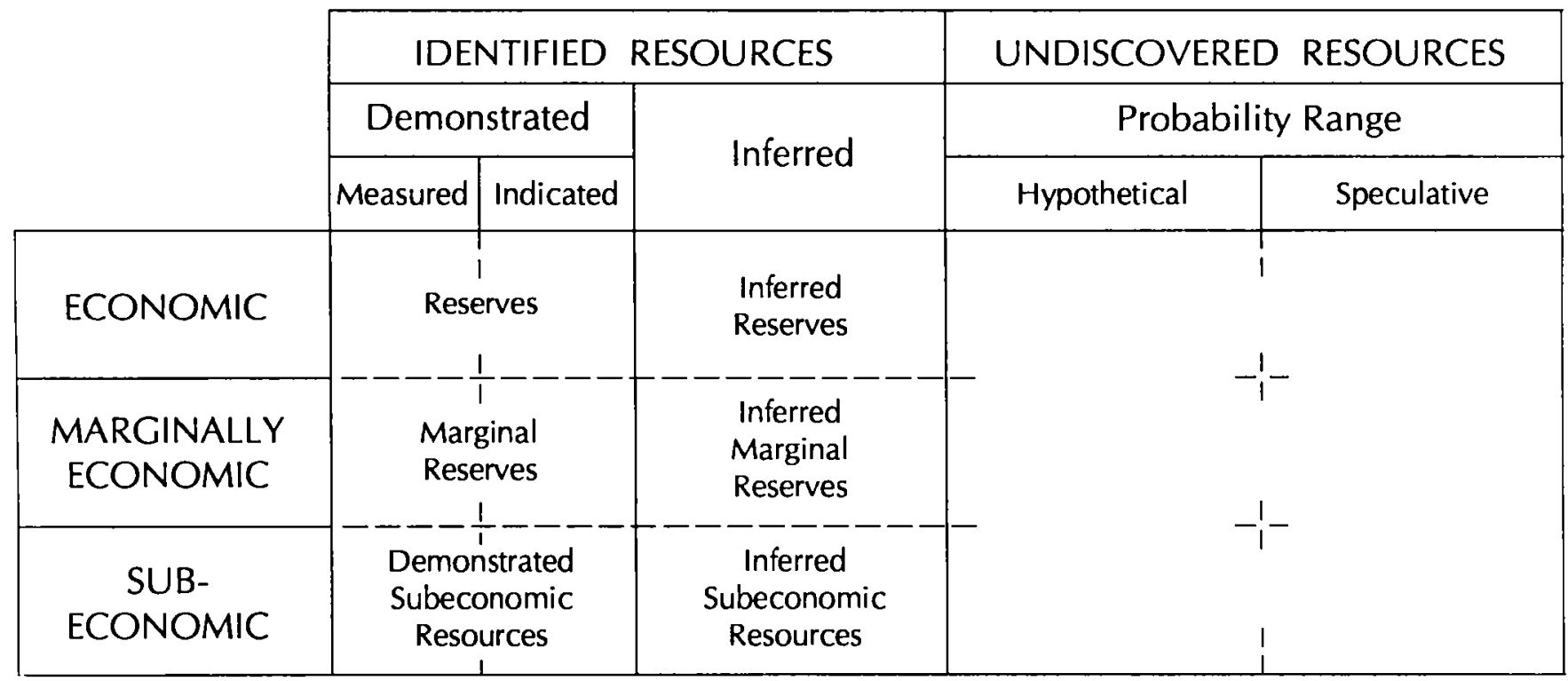

Major elements of mineral resource classification, excluding reserve base and inferred reserve base. Modified from McKelvey, V.E., 1972, Mineral resource estimates and public policy: American Scientist, v. 60, p. 32-40; and U.S. Bureau of Mines and U.S. Geological Survey, 1980, Principles of a resource/reserve classification for minerals: U.S. Geological Survey Circular 831, p. 5. 
GEOLOGIC TIME CHART

Terms and boundary ages used by the U.S. Geological Survey in this report

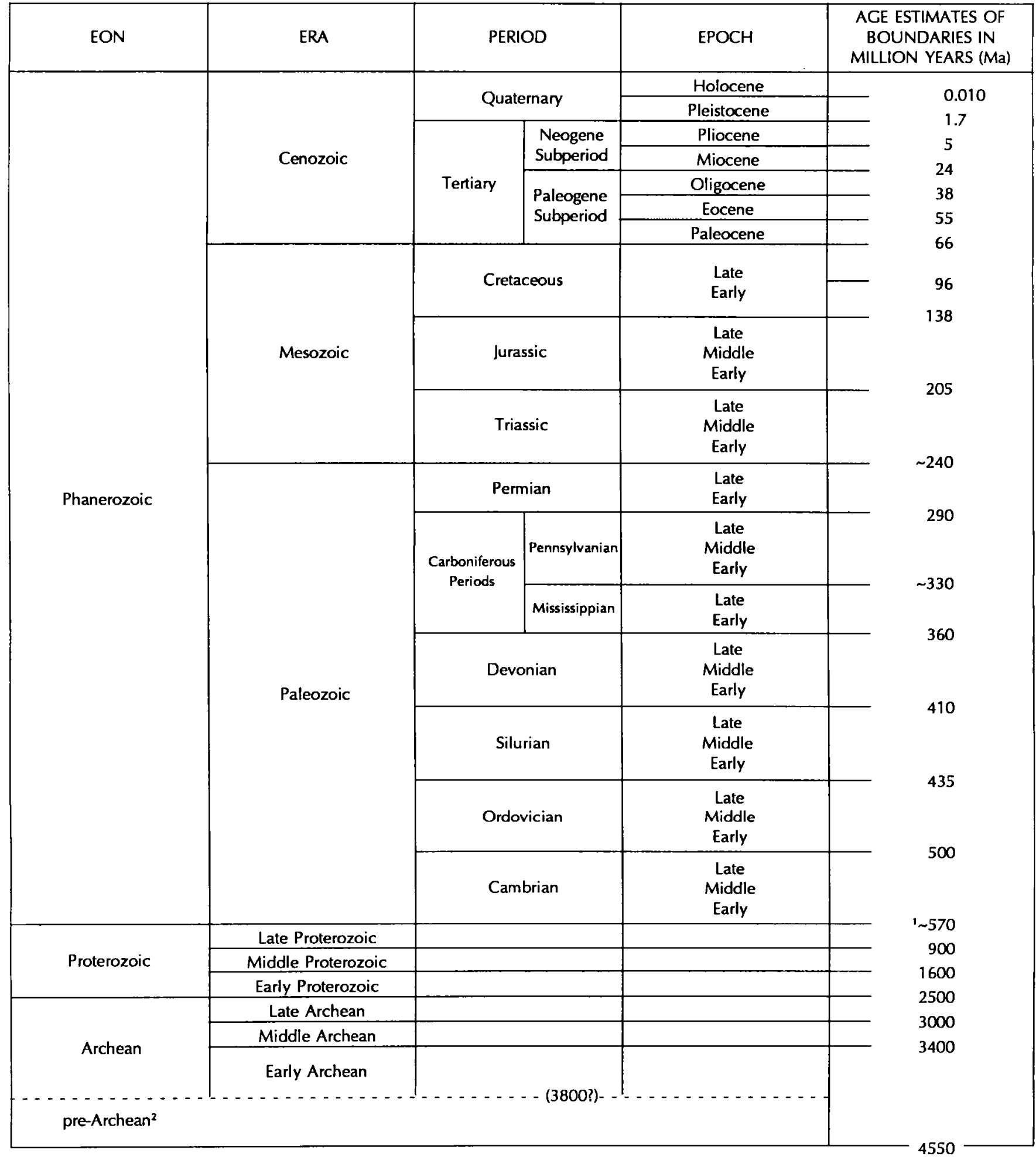

'Rocks older than $570 \mathrm{Ma}$ also called Precambrian, a time term without specific rank.

${ }^{2}$ Informal time term without specific rank. 
Table 1. Mines and prospects in and adjacent to the Clover Mountains Wilderness Study Area, Lincoln County, Nevada

[* indicates outside study area]

\begin{tabular}{llll}
\hline Map & Name & Workings and production & Sample and resource data \\
No. & & Summary
\end{tabular}

1* Pennsylvania Mineralized quartz breccia in Tertimine (Culver- ary diorite along a sheared zone well, Jumbo) that strikes N. $20^{\circ} \mathrm{W}$. and dips $20^{\circ}$ NE. The replacement quartz breccia has been traced for $3,000 \mathrm{ft}$ along strike and to a depth of 620 $\mathrm{ft}$ in workings. The zone is 3 to 7 $f t$ thick in the old Pennsylvania workings and as much as $70 \mathrm{ft}$ thick in the vicinity of the proposed Jumbo pit. The diorite is in contact with Cambrian sedimentary rocks to the south and is overlain by Tertiary volcanic rocks to the east. The quartz breccia contains limonite, malachite, and chrysocolla; diorite-carbonate contacts to the south contain mineralized calc-silicate pods. prospect prospect hematite zone along bedding in limestone strikes N. $20^{\circ}$ W., dips $20^{\circ} \mathrm{SW}$, and is 1.5 to $2.4 \mathrm{ft}$ thick. The zone is exposed for $20 \mathrm{ft}$ in workings and intermittently for 70 $\mathrm{ft}$ to the southeast where it is jasperoidal near its contact with overlying thyolite.

A vertical, hematitic breccia zone in dolomite strikes $\mathrm{N} .30^{\circ} \mathrm{W}$. The zone contains quartz, opal, pyrite, and sparse galena, and is $6 \mathrm{ft}$ thick in the main shaft but exposed for less than $30 \mathrm{ft}$ along strike. Segments of oher, similar, subparallel shear zones are exposed to the north and east; they are narrow and discontinuous.

A limonitic shear zone in andesite strikes N. $65^{\circ} \mathrm{W}$. and dips $70^{\circ} \mathrm{NE}$. each about $6 \mathrm{ft}$ wide and $3 \mathrm{ft}$ deep. The zone contains quartz lenses and stringers and is stained with manganese oxides. It is exposed for $140 \mathrm{ft}$ along strike; thickness averages $3 \mathrm{ft}$. Argillic alteration in overlying ash-flow tuff is pervasive, and iron-oxide staining is intense along a striking $\mathrm{N} .70^{\circ} \mathrm{W}$. striking shear zone.
Three shafts 620,265 , and $110 \mathrm{ft}$ deep; eight pits and open cuts. Ore mined before 1881 yielded \$20-25/ton (Angel, 1958, p. 485); additional shipments made in 1914 (Marshall, 1948, p. 6). U.S. Bureau of Mines' records show that 74 tons of ore mined in 1941-42 yielded 50 oz gold, 691 oz silver, $1,280 \mathrm{lb}$ copper, and $192 \mathrm{lb}$ lead. Shallow shafts and trenches are just south of the Pennsylvania shafis at the old Culverwell and Jumbo workings where about 1,500 tons of ore that averaged $1.75 \mathrm{oz} / \mathrm{ton}$ gold, $7.6 \mathrm{oz} /$ ton silver, 0.5 percent lead, and 0.08 percent copper were mined between 1932 and 1953. About 90,000 tons of ore that averaged $0.11 \mathrm{oz} / \mathrm{ton}$ gold and 1.0 to $1.5 \mathrm{oz} /$ ton silver were mined in 1986 for heap leaching. By October 1986, about 2,000 oz gold and 15,000 oz silver were recovered. At least nine pits and two adits with no record of production are south of the Jumbo workings.

Two trenches, 18 and $20 \mathrm{ft}$ long, are

Twelve samples of quartz breccia from the Jumbo pit area contain as much as 0.06 oz/ton gold and 1.1 oz/ton silver, and average $0.01 \mathrm{oz} /$ ton gold, $0.2 \mathrm{oz} /$ ton silver, 181 parts per million (ppm) copper, 75 ppm lead, and $52 \mathrm{ppm}$ zinc. Thirteen samples, mainly of tuff or diorite along contacts with carbonate rocks contain, 0.0002 to $0.0927 \mathrm{oz} / \mathrm{ton}$ gold. A 700,000-ton resource of leachable ore that contains $0.039 \mathrm{oz} /$ ton gold was estimated by the owner. The current operators identified a 100,000-ton resource that was mostly mined in 1986 .

One of two samples from the workings contains $0.0069 \mathrm{oz} /$ ton gold; no gold was detected in the other. The samples also contain 0.015 and 0.031 oz/ton silver, 15 and $19 \mathrm{ppm}$ copper, less than 10 and $66 \mathrm{ppm}$ lead, and 42 and $190 \mathrm{ppm}$ zinc, respectively. A sample from jasperoid in outcrop contains no detectable gold and 0.013 oz/ton silver.

The main breccia zone is exposed in a 60 -ft-deep vertical shaft. Three shallow trenches and a 10-ft-deep vertical shaft are on the other subparallel zones.

Four prospect pits are along the shear zone in andesite. One sloughed pit may have been $10 \mathrm{ft}$ deep.

A sample from the main breccia zone contains 0.0220 oz/ton gold, 1.37 oz/ton silver, 0.008 percent copper, 4.1 percent lead, and 1.5 percent zinc. Three samples from the other zones contained 0.0004 to $0.017 \mathrm{oz} /$ ton gold, 0.05 to 1.20 oz/ton silver, 0.001 to 0.016 percent copper, 0.004 to 4.4 percent lead, and 0.02 to 2.7 percent zinc.

Gold was detected $(0.0002$ oz/hon) in one of two samples from the shear zone in andesite. No silver or significant amounts of other elements were detected. Of five samples of ash-flow tuff, one contains 0.0008 oz/ton gold. No other elements of economic significance were detected. 
Table 1. Mines and prospects in and adjacent to the Clover Mountains Wilderness Study Area, Lincoln County, NevadaContinued

\begin{tabular}{llll}
\hline $\begin{array}{l}\text { Map } \\
\text { No. }\end{array}$ & Name & Working and production & Sample and resource data \\
\hline
\end{tabular}

G* Grandview
prospect

6 Yon prospect

7

\section{Gold 23-31 prospect}

8

\section{Gold 1-22}

prospect

9*

Wall Street prospect

$10^{*}$ Gold Chance prospect

11* Cherokee 1-12 prospect
Claims were staked in 1963, they are underlain by ash-flow and ash-fall tuff. Stringers of opaline silica in the tuff are as thick as 2 in.

Welded ash flow tuff is bleached, silicified, and stained with hematite along fissures. Rhyolite dikes as much as $\mathbf{4 0} \mathrm{ft}$ thick strike northwesterly through the tuff and locally contain disseminated pyrite.

Bleached and silicified intermediate lava and tuff are $2 \mathrm{mi}$ south of the projected rim of the Caliente cauldron complex. Fissures are commonly stained with hematite.

Altered lava and tuff are $2 \mathrm{mi}$ south of the projected rim of the Caliente cauldron complex. Quartz stringers to 2 in. thick are common.

Poorly exposed quartz veins and coarse calcite stringers strike northwesterly in white, recrystallized limestone. The quartz veins are as much as $2.5 \mathrm{ft}$ thick, and contain lenses of limonitic boxwork.

A contact zone of limestone with overlying andesite is sheared, brecciated, and silicified. The zone is limonite stained and strikes N. $30-40^{\circ} \mathrm{W}$. and dips $35^{\circ} \mathrm{NE}$. Quartz stringers are along joints, and pyrite is scattered through the limestone. Shale interbeds contain cherty bands. A 10 -ft-thick felsic dike strikes $\mathrm{N} .20^{\circ} \mathrm{W}$. through the sedimentary beds.

A shear zone in silicified limestone strikes $\mathrm{N} .61^{\circ} \mathrm{E}$. and dips $30^{\circ} \mathrm{NW}$. Brecciated limestone in the zone is in a hematitic, siliceous matrix. Average thickness of a $40 \mathrm{ft}$ exposure is $3 \mathrm{ft}$. Argillized, silicified thyolitic ash-flow tuff north of the shear zone is $65-80 \mathrm{ft}$ wide and exposed for $300 \mathrm{ft}$ along a N. $10^{\circ}$ W. trend.
None

None

None

None

Four shallow prospect pits and a 20 $\mathrm{ft}$-long adit are in the quartz-bearing limestone.

Four shallow prospect pits and two trenches 30 and $40 \mathrm{ft}$ long are along limonitic contact zones. At least one drillhole is near the pits; depth is unknown.

A 62-ft adit and sloughed shaft are on the shear zone in silicified limestone. Three shallow pits and a 40-ft inclined shaft are in the altered ash-flow tuff zone $1,300 \mathrm{ft}$ north of the adit.
One grab sample of opaline silica contains $14.0 \mathrm{ppm}$ arsenic and no detectable gold, silver, antimony, mercury, or thallium.

Six of eleven samples of altered ashflow tuff contain 0.011 to $0.020 \mathrm{oz} /$ ton silver, and two of four samples from rhyolite dikes contain 0.010 and $0.011 \mathrm{oz} / \mathrm{ton}$ silver. None contain detectable gold or antimony; 13 contain 3 to $12.8 \mathrm{ppm}$ arsenic. No other elements are anomalies.

Five of ten outcrop samples contain 0.0011 to $0.0018 \mathrm{oz} /$ ton gold; six contain 0.011 to 0.012 oz/ton silver. None contain anomalous arsenic, antimony, or other elements of economic significance.

One of ten outcrop samples contain $0.0005 \mathrm{oz} / \mathrm{ton}$ gold; two contain 0.016 and $0.024 \mathrm{oz} / \mathrm{ton}$ silver. None contain anomalous arsenic, antimony, or other elements of economic significance.

Chip sample of massive quartz con tained $0.013 \mathrm{oz} / \mathrm{ton}$ silver. Sample of coarse calcite contain $0.050 \mathrm{oz} / \mathrm{ton}$ silver, 0.20 percent lead, and 0.81 percent zinc. Grab sample of vein quarz in talcose limestone contain $0.014 \mathrm{oz} /$ ton silver. Grab sample of limonitic boxwork contain 0.0007 oz/ton gold and 0.049 oz/ton silver.

One of seven chip samples from near the limestone- andesite contact contained $0.015 \mathrm{oz} /$ ton gold, and 160 ppm molybdenum. Several samples contained silver $(0.011$ to $0.103 \mathrm{oz}$ ton). No other elements were found to be anomalous.

Three of four samples from the hematitic, sheared silicified limestone contained 0.016 to $0.025 \mathrm{oz} / \mathrm{ton}$ silver. Two of four samples from the altered ash-flow tuff contained 0.047 and $0.052 \mathrm{oz} /$ ton silver. No samples contained detectable gold or antimony. Six samples contained $82-490$ ppm barium (average 278 ppm), and 24-140 ppm molybdenum (average $72 \mathrm{ppm}$ ). 


\section{Mineral Resources of Wilderness Study Areas: Southeastern Nevada}

This volume was published as separate chapters A-D 


\section{DEPARTMENT OF THE INTERIOR DONALD PAUL HODEL, Secretary \\ U.S. GEOLOGICAL SURVEY \\ Dallas L. Peck, Director}

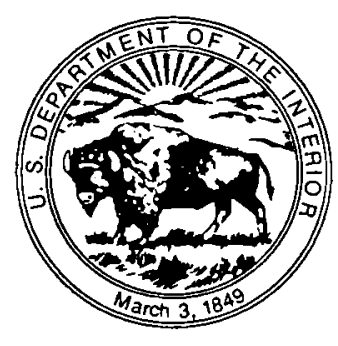




\section{CONTENTS}

[Letters designate the separately published chapters]

(A) Mineral Resources of the South Pahroc Range Wilderness Study Area, Lincoln County, Nevada, by Barry C. Moring, H. Richard Blank, Jr., Harlan N. Barton, and Terry R. Neumann.

(B) Mineral Resources of the Mormon Mountains Wilderness Study Area, Lincoln County, Nevada, by Daniel R. Shawe, H. Richard Blank, Jr., Brian P. Wernicke, Gary J. Axen, Harlan N. Barton, Gordon W. Day, and Richard L. Rains.

(C) Mineral Resources of the Meadow Valley Range Wilderness Study Area, Lincoln and Clark Counties, Nevada, by E.H. Pampeyan, H.R. Blank, Jr., and H.W. Campbell.

(D) Mineral Resources of the Clover Mountains Wilderness Study Area, Lincoln County, Nevada, by Barry Moring, H. Richard Blank, Jr., James D. Hoffman, and Edward L. McHugh. 
GPO 685-041/9771 


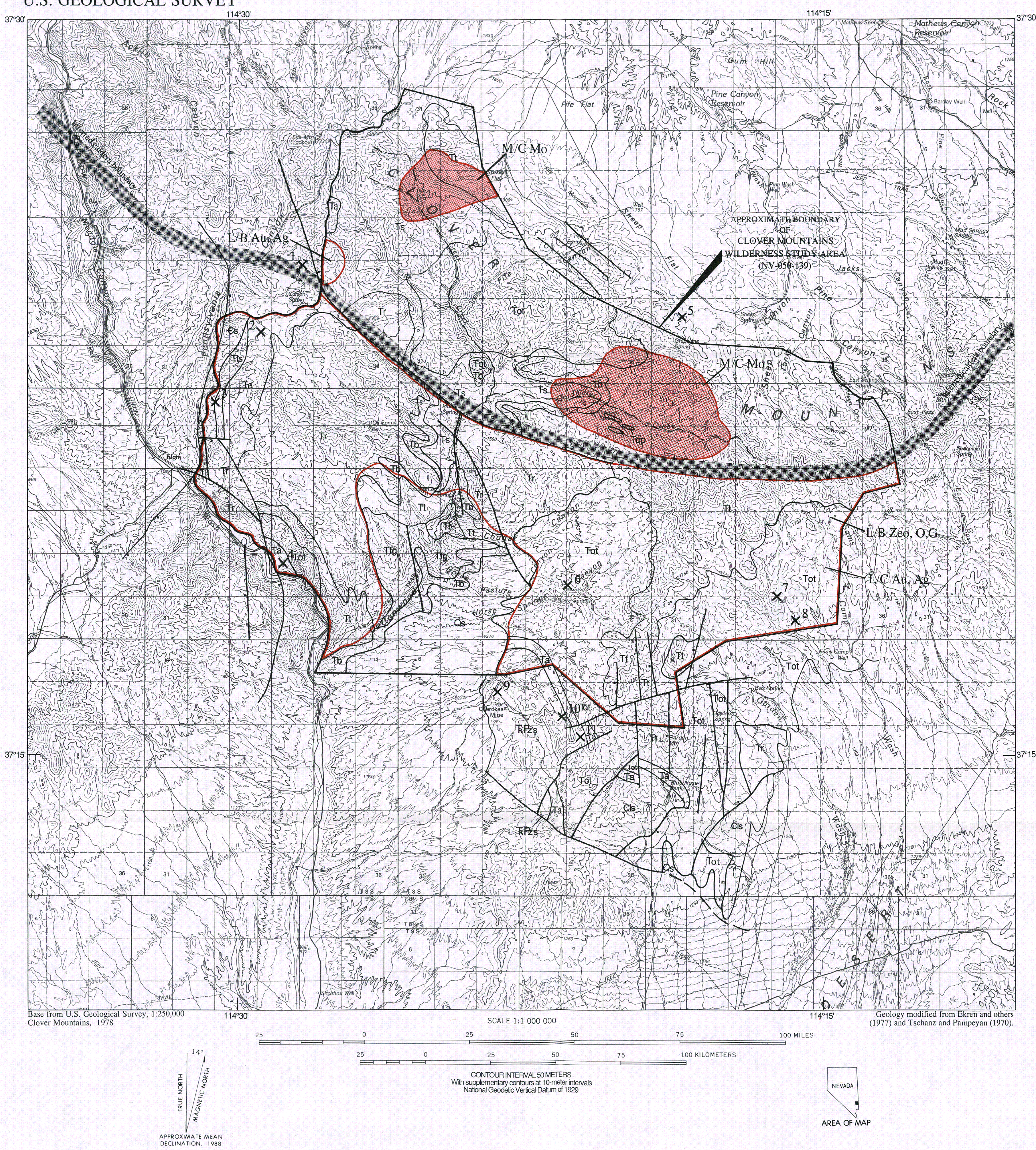

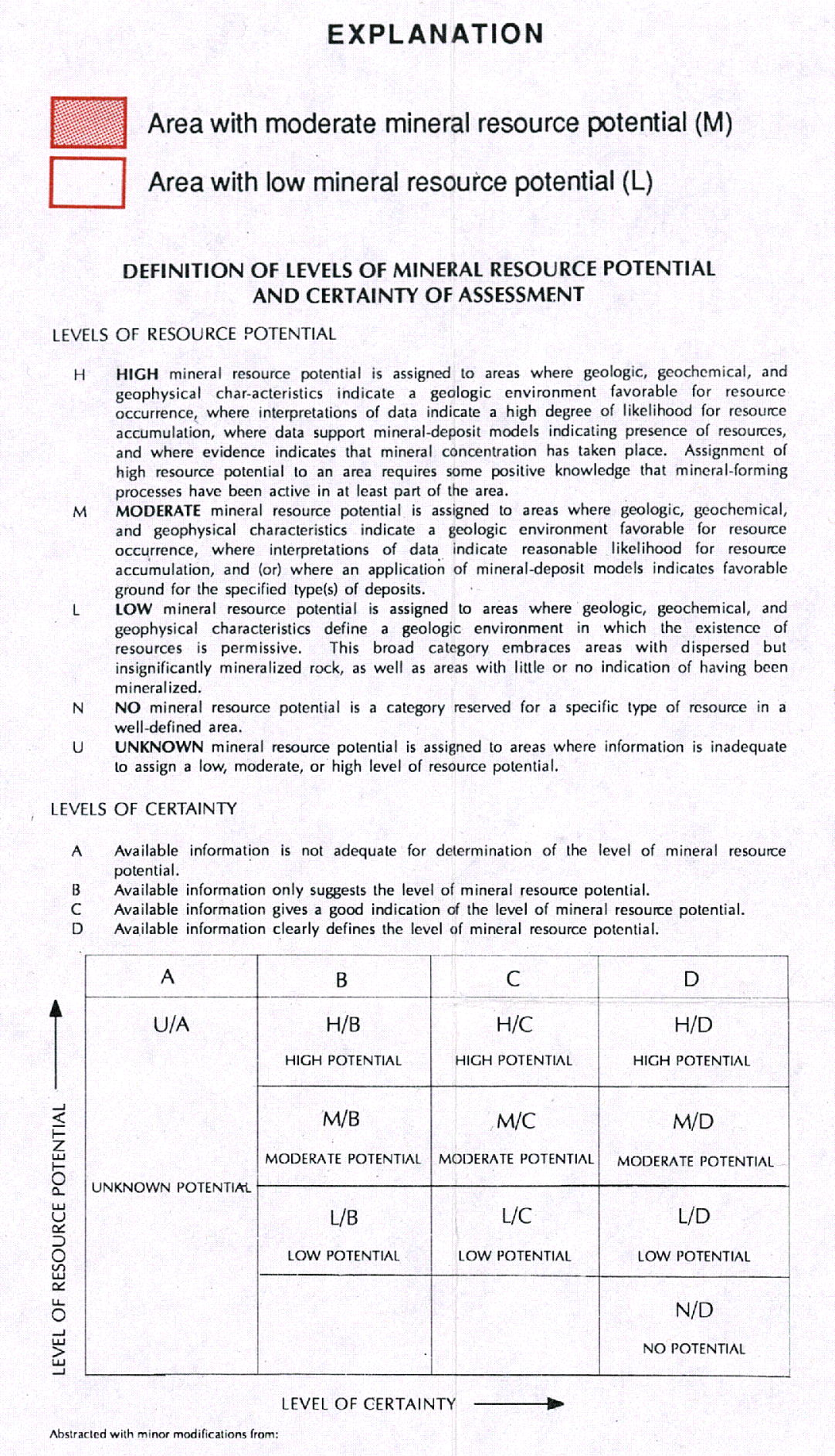

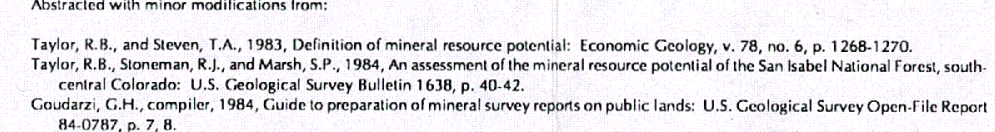
$\begin{array}{ll} & \text { Commodities } \\ \text { Mo } & \text { Molyddenum } \\ \text { Au } & \text { Gold } \\ \text { AU } & \text { Silve } \\ \text { Zeo } & \text { Zolite } \\ \text { O,G } & \text { Oil and gas }\end{array}$
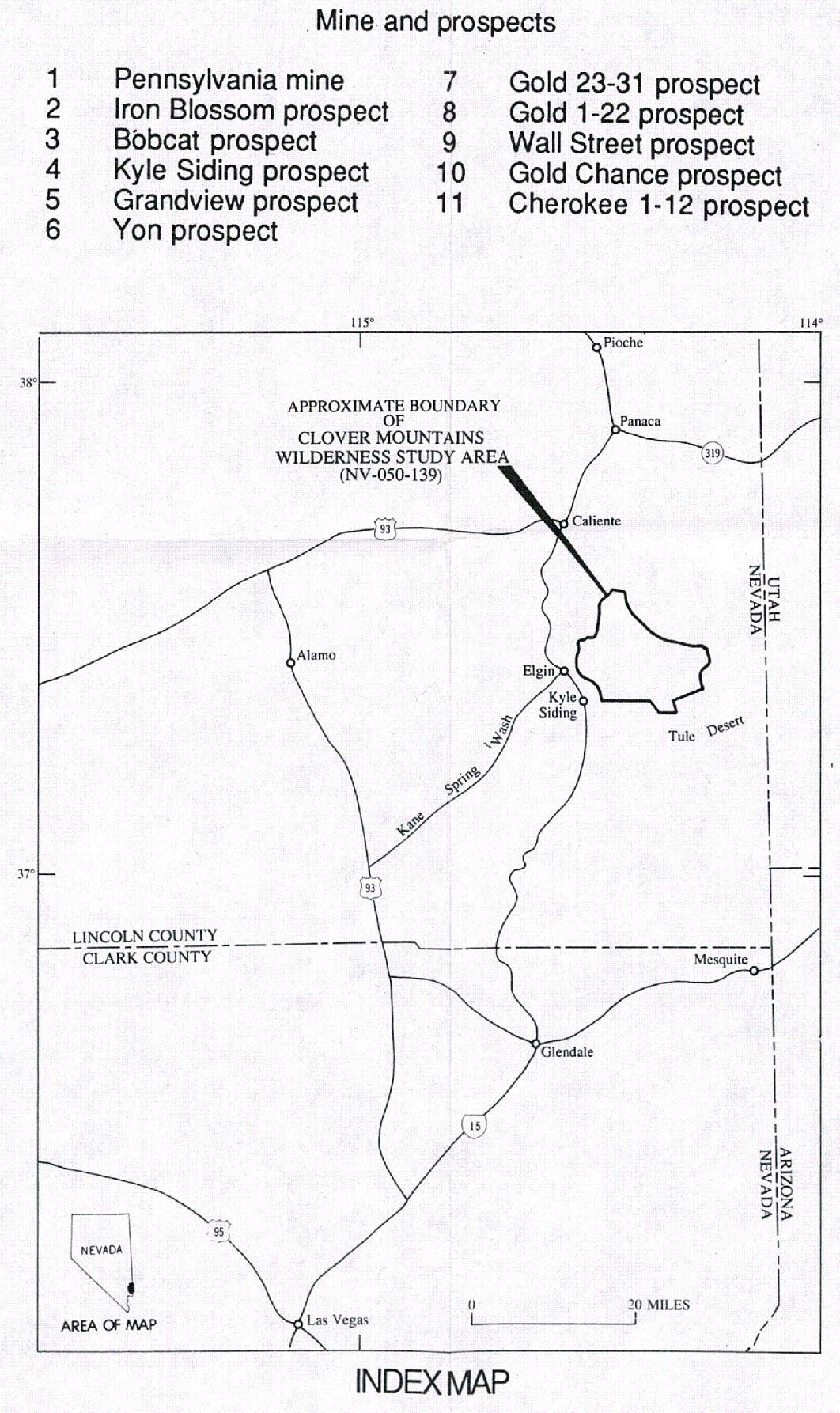

BULLETIN 1729-D

CORRELATION OF MAP UNITS

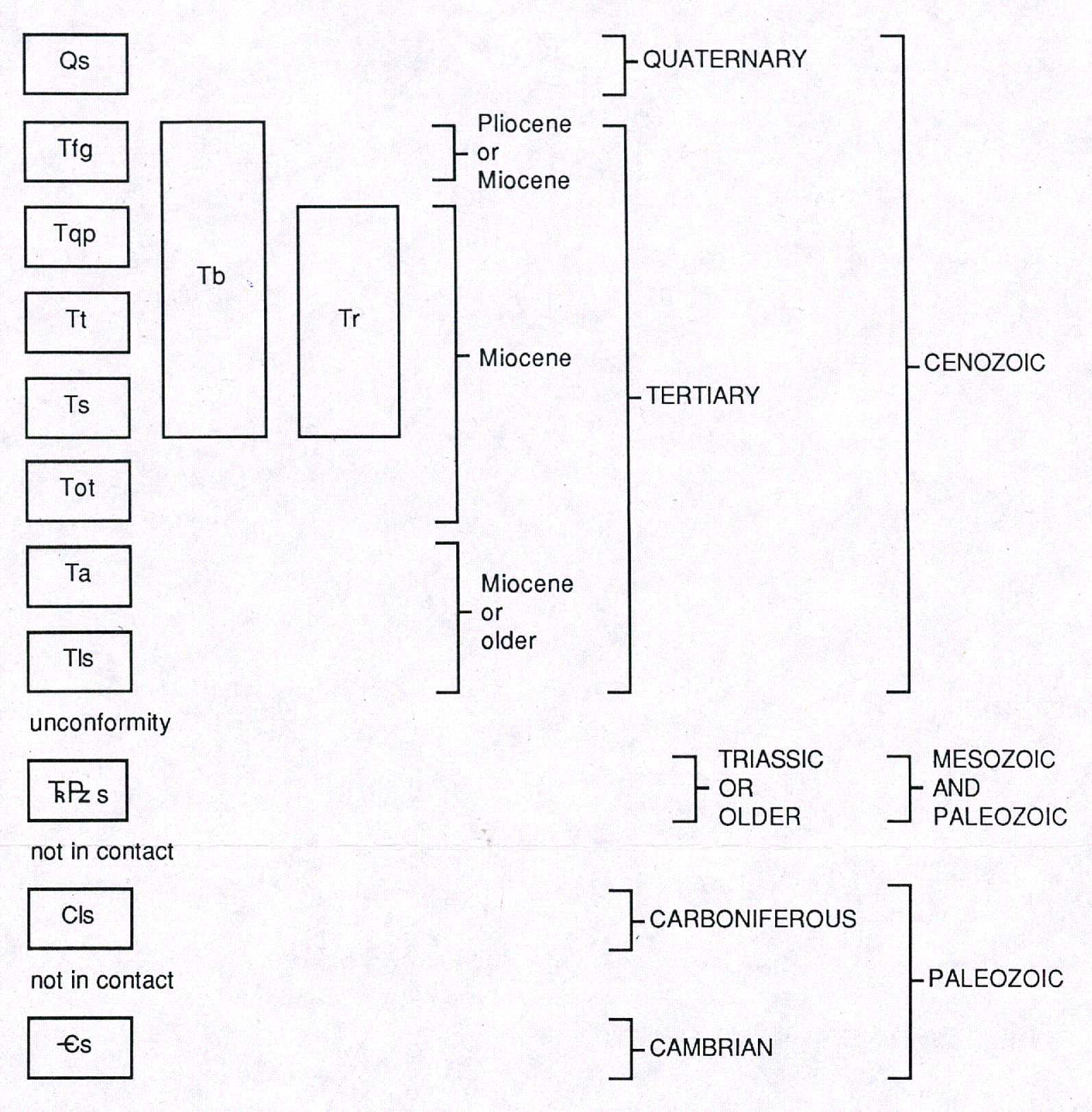

as Surricial deposits (Quaternary)-Unnonsolidated sand and gravel

Tfg Fanglomerate (Plliocene or Miocene)-Partially consolidated, thin-

Tb Basalt, undivided (Pliocene and Miocene)-Basalt flows and

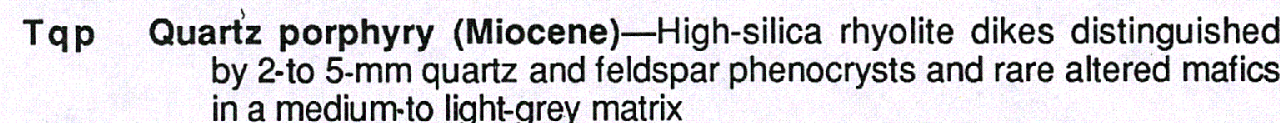

Tt Tuffaceous rocks (Miocene)-Rhyolte and itrodactite tuft; primarily
composed of the 14 -Ma Ox Valley Tuff

Ts Sedimentary rocks (Milocene)-Volcani ilastic sandstone and

iite (Miocene)-Divitrified rhyolite flows and don

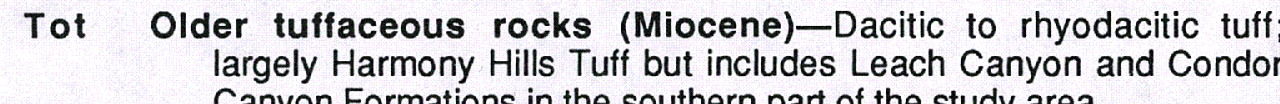

Ta Andesite (Miocene and older)

Limestone (Miocene and older)-Bed

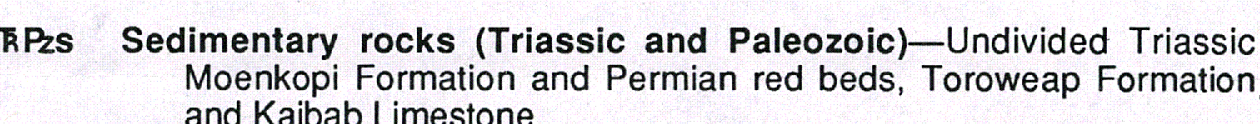

Cls Limestone and sandstone (Carboniterous)-Undivided

Es Sedimentary rocks Coambrian)-Undivived Prospect Mountain

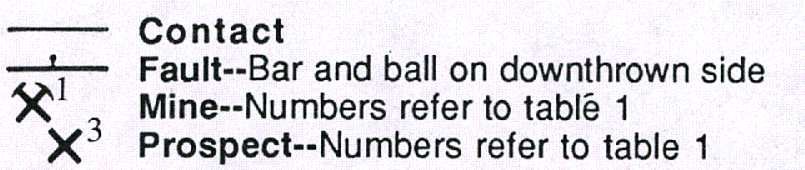

MINERAL RESOURCE POTENTIAL MAP OF CLOVER MOUNTAINS WILDERNESS STUDY AREA, LINCOLN COUNTY, NEVADA 
